\title{
The effects of educational systems, school- composition, track-level, parental background and immigrants' origin on the achievement of 15-years old native and immigrant students : a reanalysis of PISA 2006
}

Citation for published version (APA):

Dronkers, J., van der Velden, R. K. W., \& Dunne, A. (2011). The effects of educational systems, schoolcomposition, track-level, parental background and immigrants' origin on the achievement of 15-years old native and immigrant students : a reanalysis of PISA 2006. Researchcentrum voor Onderwijs en Arbeidsmarkt, Faculteit der Economische Wetenschappen. ROA Research Memoranda No. 6 https://doi.org/10.26481/umaror.2011006

Document status and date:

Published: 01/01/2011

DOI:

10.26481/umaror.2011006

Document Version:

Publisher's PDF, also known as Version of record

Please check the document version of this publication:

- A submitted manuscript is the version of the article upon submission and before peer-review. There can be important differences between the submitted version and the official published version of record. People interested in the research are advised to contact the author for the final version of the publication, or visit the DOI to the publisher's website.

- The final author version and the galley proof are versions of the publication after peer review.

- The final published version features the final layout of the paper including the volume, issue and page numbers.

Link to publication

\footnotetext{
General rights rights.

- You may freely distribute the URL identifying the publication in the public portal. please follow below link for the End User Agreement:

www.umlib.nl/taverne-license

Take down policy

If you believe that this document breaches copyright please contact us at:

repository@maastrichtuniversity.nl

providing details and we will investigate your claim.
}

Copyright and moral rights for the publications made accessible in the public portal are retained by the authors and/or other copyright owners and it is a condition of accessing publications that users recognise and abide by the legal requirements associated with these

- Users may download and print one copy of any publication from the public portal for the purpose of private study or research.

- You may not further distribute the material or use it for any profit-making activity or commercial gain

If the publication is distributed under the terms of Article $25 \mathrm{fa}$ of the Dutch Copyright Act, indicated by the "Taverne" license above,

Download date: 26 Apr. 2023 
Maastricht University

Research Centre for Education and the Labour Market | ROA

The effects of educational systems, school-composition, track-level, parental background and immigrants' origins on the achievement of 15-years old native and immigrant students. A reanalysis of PISA 2006

Jaap Dronkers

Rolf van der Velden

Allison Dunne

\section{ROA Research Memorandum}

ROA-RM-2011/6

Research Centre for Education and the Labour Market

Maastricht University

P.O. Box 616,6200 MD Maastricht, The Netherlands

$\mathrm{T}+31433883647 \mathrm{~F}+31433884914$

secretary-roa-sbe@maastrichtuniversity.n

www.roa.nl 


\title{
The effects of educational systems, school-composition, track-level, parental background and immigrants' origins on the achievement of 15-years old native and immigrant students. A reanalysis of PISA 2006
}

\author{
Jaap Dronkers \\ Rolf van der Velden \\ Allison Dunne
}

ROA-RM-2011/6*

May 2011

Research Centre for Education and the Labour Market Maastricht University

P.O. Box 616, 6200 MD Maastricht, The Netherlands

$\mathrm{T}+31433883647 \mathrm{~F}+31433884914$

secretary-roa-sbe@maastrichtuniversity.nl

www.roa.nl

The ROA Research Memorandum Series was created in order to make research results available for discussion, before those results are submitted for publication in journals. 


\section{Abstract \\ The effects of educational systems, school-composition, track-level, parental background and immigrants' origins on the achievement of 15-years old native and immigrant students. A reanalysis of PISA 2006}

The main research question of this paper is the combined estimation of the effects of educational systems, school-composition and track-level on the educational achievement of 15-years-old students. We specifically focus on the effects of socioeconomic and ethnic background on achievement scores and to what extent these effects are affected by characteristics of the school, track or educational system these students are in. In doing so, we examine the 'sorting' mechanisms of schools and tracks in highly stratified, moderately stratified and comprehensive education systems. We use data from the 2006 PISA (Programme for International Student Assessment) wave. Compared to previous research in this area the main contribution of this paper is that we explicitly include track-level and school-level as separate units of analyses, which leads to less biased results of the effects of characteristics of the educational system. The results highlight the importance of including track-level and school-level factors in the debate of educational inequality of opportunity for students in different education contexts. The findings clearly indicate that the effects of educational system characteristics are flawed if the analysis uses only a country and a student level and ignores the track- and school-level characteristics. Moreover the inclusion of the track-level is necessary to avoid overestimation of the school-composition effect, especially in stratified educational systems. From a policy perspective, the most important finding is that educational system are not uniformly 'good' or 'bad', but they have different consequences for different groups. Some groups are better off in comprehensive systems, while other groups are better off in moderately or highly stratified systems.

Keywords: achievement, educational system, school-characteristics, track, socioeconomic background, ethnic background

Jaap Dronkers

ROA

Maastricht University

P.O. Box 616

6200 MD Maastricht

The Netherlands

j.dronkers@maastrichtuniversity.nl

Allison Dunne

GHK Consulting Ltd.

5th Floor, 146 Rue Royale

1000 Brussels

Belgium

allison.dunne@ghkint.com
Rolf van der Velden

ROA

Maastricht University

P.O. Box 616

6200 MD Maastricht

The Netherlands

r.vandervelden@maastrichtuniversity.nl 


\section{Introduction}

The effect of characteristics of national educational systems on average achievement levels of students as well on the effect of parental socio-economic status on students' achievement has been the topic of many international comparisons. There is substantial agreement among scholars that the average achievement levels of students and the effect of parental background on these achievement levels vary systematically across national educational systems. The consensus seems to be that students have on average higher scores in comprehensive educational systems compared with equivalent students in highly stratified educational systems: countries where students follow the same curriculum up to age 16 show higher results on achievement tests than countries where students are selected into different tracks of secondary education at a very early age. Moreover the effect of parental background on the achievement of their offspring is much lower in the comprehensive systems than in the highly stratified ones (Breen \& Jonsson, 2000; Buchmann \& Hannum, 2001; OECD, 2005).

Most of these studies use a simple two-level model with a distinction between countries (with characteristics of the national educational system) and students (with individual and family characteristics). They thus ignore the fact that there are more levels that affect the achievement of students. Students are nested in schools and within schools in different tracks and all of these environments are a source of variation in achievement levels.

Recently Dunne (2010) and Dronkers (2010a) introduced a three-level model: countries, schools and students. They showed that school characteristics like socio-economic composition and ethnic diversity have substantial effects on achievement levels and also affect the relation between parental background and achievement. Moreover these school characteristics seem to mediate some of the effects of the characteristics of educational system that were found earlier. They show that one of the reasons why the relation between parental background and achievement is stronger in stratified educational systems is that these systems show stronger effects of the particular school a student attends.

However these two papers still do not include the level of the track as a separate level in the analysis. This is a serious omission if we consider stratified systems. It is unlikely that the results of stratified systems pertain to all of the tracks that can be distinguished. In fact it might well be that the negative results of such systems only pertain to the lower or vocational tracks in these systems while opposite results might be found for higher or more general tracks. Also they identified schools only by administrative unit and not by track-level. This means that students in schools with different tracks are all regarded as being exposed to the same environment. Both omissions can produce flawed results, because track-level has a strong effect on achievement.

Therefore this paper wants to improve the Dunne (2010) and Dronkers (2010a) papers on two points: 1. Inclusion of track characteristics; 2. Use of 'track-within-school' level, indexed by school-identification number, track-level and vocational orientation instead of the administrative school-level and define school-composition characteristics at this level.

The main research question of this paper is the estimation of the effects of educational systems, school-composition and track-level on the educational achievement of 15-years-old students. We specifically focus on the effects of socio-economic and ethnic background on achievement scores and to what extent these effects are affected by characteristics of the school, track or educational system these students are in. In doing so, we examine the 'sorting' mechanisms of schools and tracks in highly stratified, moderately stratified and comprehensive education systems.

We will analyze native and immigrant students separately to test whether educational systems have the same consequences for both groups. Heus \& Dronkers (2010a) found that 
immigrant students did on average better in a moderately stratified educational system, while native students did on average better in a comprehensive educational system.

We use the 2006 data wave of the Program for International Student Assessment PISA (OECD, 2007). We include only those countries that provide information about the countries of birth of students and parents, because earlier research (Levels, Dronkers \& Kraaykamp, 2008) has shown that these countries of origin are important control variables. Therefore the analysis is based on 8,521 immigrant students from 35 different countries of origin, living in 15 Western destination countries and 72,315 native students in these 15 countries. We use a four-level multi-level analysis with cross-classified origin and destination levels for the equations with immigrant students, and a normal four-level multi-level analysis for native students.

The results highlight the importance of including track-level and school-level factors in the debate of educational inequality of opportunity for students in different education contexts. The findings clearly indicate that the effects of educational system characteristics are flawed if the analysis uses only a country and a student level and ignores the track- and school-level characteristics. Moreover the inclusion of the track-level is necessary to avoid overestimation of the school-composition effect, especially in stratified educational systems. From a policy perspective, the most important finding is that educational system are not uniformly 'good' or 'bad', but they have different consequences for different groups. Some groups are better off in comprehensive systems, while other groups are better off in moderately or highly stratified systems.

The remainder of this paper is organized as follows. In section 2 we present an overview of the literature followed by the hypotheses. Section 3 describes the data and operationalisation of the variables. Section 4 describes the models and section 5 the main results. Section 6 concludes.

\section{Overview of the literature ${ }^{\text {ii }}$}

This paper builds, next to Dunne 2010, on previous comparative work that addressed the issue of educational inequality of opportunity depending on the degree of stratification of educational systems (Treiman \& Yip, 1989; Muller \& Karle, 1993; Shavit \& Blossfeld, 1993; Erikson \& Jonsson, 1996; Filmer \& Pritchett, 1999; Shavit, Arum \& Gamoran, 2007; Pfeffer, 2008). The reproduction of inequality is a central concern of sociologists. This reproduction is not only affected by characteristics of the educational system, but also by characteristics of the school, specifically the school's socioeconomic composition. However, the effect of the school's socioeconomic composition and its 'sorting' effect may vary across countries. One reason the composition effect may vary across countries is that countries vary in the way they sort students for instruction during secondary education. In this section we will first present an overview of the research on school factors and subsequently on the institutional aspects of educational systems.

\subsection{School Factors}

Since the Coleman Report (Coleman, 1966) in the United States and the Plowden Report (Peaker, 1971) in the United Kingdom, there has been a debate on the relative importance of individual and school factors. These reports concluded that individual family background was more important than school factors in determining children's educational achievement. Much research has concentrated, since these reports, on assessing the relative importance of individual versus school effects.

Borrowing from both the economic and organisational definitions of school effectiveness (Scheerens \& Bosker, 1997), we define schools as organisations that have 
particular processes in place to turn inputs into output. Inputs to a school include the prior characteristics of students, whereas outputs include student achievement. The transformation process within a school is composed of a number of factors which include teaching and learning methods, track choices and organisational conditions that make it possible for students to learn. Early research already showed the importance of parental socioeconomic status on educational achievement (Blau \& Duncan, 1967; Jencks, 1972, Jencks et al, 1979, Hauser \& Sewell, 1986). Later research also identified a link between differences in achievement scores and differences in the composition of the student body within the schools. They show that the mean socioeconomic background of a school has an impact on student achievement over and above the effect of a student's individual socioeconomic background (Gamoran, 1992; Willms, 1986, 1992).

The Organisation for Economic Co-operation and Development (OECD) (2005) used the PISA 2000 data to look at how the socioeconomic composition of schools affects achievement from a comparative perspective. In line with the research mentioned above, the report concluded that the school's average socioeconomic status had a statistically significant impact on student performance in reading literacy in all but four countries (Denmark, Finland, Iceland and Korea). Furthermore, school-composition effects far outweighed the impact of other policy-amenable characteristics. Together with individual characteristics, school's socioeconomic composition explained on average 69 per cent of the school effects, compared to only 6 per cent explained by policy-amenable school characteristics.

The results from these studies show the strong link between the socioeconomic composition of the school and student performance and achievement. However, studies have not shown whether this strong relationship between school-composition and student achievement varies systematically across educational systems. Nevertheless this seems plausible: as countries vary in the way they sort their students for instruction, so will composition effects vary across countries.

One important sorting mechanism is ability grouping or tracking. Many studies have found evidence that early division of students into ability groups or tracks increases inequality (Kerckhoff, 1986; Gamoran, 2004; Oakes, Gamoran \& Page, 1992). Research has explored achievement and inequality in distinct school types (Hargreaves, 1967; Ammermuller, 2005; Dustmann, 2004), in distinct tracks (Rosenbaum, 1976; Metz, 1978; Oakes, 1985; Gamoran, 1992; Gamoran et al., 1995) and placement into sets (or curricular differentiation; Lucas, 1999). Although these all represent different ways to differentiate students into ability groupings, all types of ability grouping result in unequal educational opportunity.

Ability grouping is not just a school characteristic but most often a characteristic that directly results from the institutional design of the educational system. We will explore this in more detail in the section below.

\subsection{Stratification in Educational Systems}

Educational institutions have been referred to by Spring (1976) as society's 'sorting machine'. Organisational characteristics of schools and education systems have the effect of channelling students into different educational paths and further life chances. All industrialised countries use organisational mechanisms to sort students into hierarchically arranged tracks, but these mechanisms vary in both their nature and also in their timing. Hopper (1968:30) argued that "the structure of educational systems, especially those within industrial society, can be understood primarily in terms of the structure of their selection processes.” Systems can be identified as those that use separate school types to stratify students, those that have a high level of within-school/internal stratification without distinct school types, and systems that are comprehensive with low levels of within-school differentiation. 
Early in the debate on the impact of how countries sort their students for instruction, Turner (1960) contributed to the discussion by characterising educational systems as being either contest mobility or sponsored mobility systems. He described comprehensive education systems as 'contest mobility' and described the objective as being "to train as many as possible in the skills necessary for elite status so as to give everyone a chance to maintain competition at the highest pitch" (Turner, 1960: 863). Turner labelled highly selective systems as being 'sponsored mobility' and the objective of such systems is to "indoctrinate elite culture in only those presumably who will enter the elite, lest there grow a dangerous number of 'angry young men' who have elite skills without elite station” (Turner, 1960: 863).

Following this argument many studies have looked at the degree of stratification of educational systems and its impact on inequality of educational opportunity. Studies have revealed the variability across countries in the magnitude of family background effects on student outcomes (Buchmann \& Hannum, 2001) and how this is partly explained by the way in which a country sorts students for instruction (Hanushek \& Woessmann, 2006). Findings from Breen \& Jonsson (2000), Mare (1993), and Shavit \& Blossfeld (1993), suggest that comprehensive school reform in countries with previously highly stratified education systems reduced inequality of educational opportunity. However, Breen \& Jonsson (2005) in their review of inequality of opportunity in a comparative perspective, suggest the need to "draw on evidence from more countries."

The OECD (2005) report "School Factors Related to Quality and Equity, Results from PISA 2000," which utilised data from PISA 2000, is one example where evidence was drawn from a wide range of countries. The results indicate the relevance of the structure of secondary education in each participating country. The report used age of selection as an indicator of institutional differentiation and considered its effect on student achievement. The results indicate that education systems with the lowest degree of differentiation achieved "the highest mean student performance in reading literacy" (OECD, 2005:62). Hanushek \& Woessmann (2006) also found evidence that early tracking reduced mean performance using the PISA 2000 data.

The OECD report also indicated that in countries with early selection, the correlation between students' socioeconomic background and students' performance was stronger. These findings supported Kerckhoff's (1995) argument that the effects of family socioeconomic status on educational outcomes were stronger in highly stratified systems of education. Later analysis of PISA data by Marks, Cresswell \& Ainley (2006) confirmed this finding that countries with highly tracked systems tended to show stronger relationships between socioeconomic background and achievement. Horn (2009) also concluded that the early age of selection in some countries has a close link with high inequality of opportunity. Pfeffer (2008:556) looked at which nations were most successful in reducing the influence of family background on educational attainment by using the International Adult Literacy Survey and found that "rigid education systems with dead-end educational pathways appear to be a hindrance to the equalisation of educational opportunities.” Evidence from Hanushek \& Woessmann (2006) showed that increased inequality within highly stratified education systems was a result of students in the lower percentiles losing more than the gain amongst students in the upper ones. Lower performers suffered more in highly stratified systems, resulting in a decreased mean performance.

\subsection{Dunne (2010) and Dronkers (2010a) results}

A major drawback of many of the previously mentioned studies is that they fail to combine the two lines of research: the effects of school factors and the effects of characteristics of the educational system. They either concentrate on the effects of schools or they concentrate on the effects of educational systems. Both may produce flawed results as 
the effects of schools may differ across different educational systems and part of the effects of educational systems is in fact produced by schools. Recently Dunne (2010) and Dronkers (2010a) made a major improvement by introducing a three-level model in the analysis: countries, schools and students.

Using PISA 2006 data Dunne selected twenty-four countries that represent a wide range of comparable societies. The countries selected are Australia, Austria, Belgium, the Czech Republic, Canada, Denmark, Finland, Germany, Greece, Hungary, Ireland, Italy, Luxembourg, the Netherlands, New Zealand, Norway, Poland, Portugal, Spain, Sweden, Switzerland, the United Kingdom, the United States. ${ }^{\text {iii }}$ She applied a three-level model (students, school, countries) and distinguished between native and immigrant students, with only two dummies to control for first and second generation.

She found that students in comprehensive schooling systems have higher overall average achievement which appears to reflect the fact that students in lower socioeconomic composition schools do not lose as much as those in low socioeconomic composition schools in highly stratified education systems. Also, she found very little difference in the average achievement of students in highly stratified education systems and moderately stratified education systems.

Inequality of opportunity at the individual-level appeared not to be as Dunne expected from the evidence in previous research. Students from a higher socioeconomic background actually achieve less in highly stratified education systems than their counterparts in comprehensive systems, unless they are in high socioeconomic composition schools. Therefore, although inequality in educational opportunity is larger in highly stratified systems, it is mediated through school-composition effects. Still, there is a very small individual social background effect within schools in highly stratified education systems.

The degree of stratification of the educational system determines the extent to which the socioeconomic composition of the school becomes a crucial element in the achievement of students. Placement into a higher socioeconomic school is a more significant condition for achievement in highly stratified systems. In comprehensive systems, achievement is very similar across schools with different socioeconomic compositions; therefore there is an advantage for those in lower socioeconomic composition schools in this system compared to those in low socioeconomic schools in highly stratified education systems. On the other hand, individual socioeconomic background has a stronger effect on achievement within schools in comprehensive education systems.

Interestingly, although average student achievement varied greatly depending on the school's socioeconomic composition in highly stratified education systems, within schools the gap in achievement between students from the top and the bottom socioeconomic backgrounds was relatively narrow in comparison to students in comprehensive systems and moderately stratified systems. It appears that there is greater between-school equity within comprehensive education systems, but within-school equity is higher in highly stratified systems. Therefore, it may be more difficult for lower class students to enter higher socioeconomic composition schools in highly stratified education systems, but once these students have entered such schools the effect of their individual background does not hinder them so strongly to achieve high scores.

Dronkers (2010a) also used the 2006 PISA data, based on a slightly different selection of countries than Dunne. He included only those countries that provide information about the countries of birth of students and their parents, because he needed that information for the measurement of ethnic diversity. He found that a greater ethnic diversity of schools hampers the educational performance of both natives and immigrants to a similar degree. However, the negative effect is smaller in education systems with a low degree of stratification in secondary education, while the effect is greatest in education systems with a high degree of stratification. 
Contrary to his expectations a greater diversity in the socio-economic composition of a school has no effect on the educational performance of natives and immigrants. The socioeconomic composition of a school, on the other hand, is of great importance. He found relatively few differences in the effect of the average parental educational level of students at school in the different education systems.

Dronkers (2010a) also found that students from non-Islamic Asia have an advantage when it comes to educational performance, compared to immigrants from other origin countries. Students from Islamic countries have a substantial disadvantage in educational performance compared to other immigrants.

Finally Dronkers (2010a) found that education systems do not always have the same positive or negative effects on the achievement of native students and students with an immigrant background.

\subsection{Hypotheses}

As indicated above the studies by Dunne (2010) and Dronkers (2010a) distinguish three levels in the analyses: countries, schools and students. Although this is an improvement compared to the previous two-level studies, these studies are still biased as they ignore one of the key levels, the level of track. Track placement is one of the major characteristics affecting inequality of educational opportunity and it serves as the 'sorting' mechanism of educational systems. It is therefore strange that this level has never been separately identified in previous analyses. Ignoring this level assumes that having a strongly stratified system will have the same effect for the students in the higher as well as the lower tracks. Similarly, ignoring this level assumes that school factors have the same effect for students of all the tracks within that school. Both assumptions are very unlikely. Our first three hypotheses can be seen as improving the hypotheses of Dunne (2010) by explicitly including the track-level as an additional explanatory level. We have added two additional hypotheses, one about the possible different effect of educational systems for immigrants and natives (based on the analysis of Heus \& Dronkers, 2010) and a second one about reproduction by the combination of individual parental class and school-composition (Bourdieu \& Passeron, 1977).

Educational systems, school-composition, track and parental ESCS (Economic, Social and Cultural Status)

1. Track placement explains a substantial part of the effect of ESCS school-composition on achievement, but mostly in highly stratified educational systems, due to the institutionalized borders in these systems.

2. The positive effect of ESCS school-composition on achievement is strongest in highly and moderately stratified systems, because ESCS school-composition indicates both the level of the track and ESCS neighborhood-composition, while ESCS school-composition in comprehensive educational systems indicates only differentiation in ESCS neighborhoodcomposition. But if one controls for track-level, this stronger effect of ESCS schoolcomposition in highly and moderately stratified systems should disappear.

3. If one controls for track placement, the effect of individual ESCS on achievement is stronger in comprehensive systems: the lack of selection into hierarchical track-levels forces higher class parents to use their cultural and social capital more to ensure sufficient schoolperformance at age 15 .

Immigrant students and educational systems

4. Students with an immigrant background have the highest achievement in strongly stratified systems, because these provide them with clear information about their scholastic 
requirements or in comprehensive educational systems, because these do not have institutionalized borders, which might preclude higher educational performances.

\section{Reproduction}

5. The interaction effect of individual ESCS and ESCS school-composition on achievement is positive and equal in all educational systems, because this combination of individual and school-composition ESCS is an indicator of a higher level of unmeasured cultural and financial capital of parents and school.

\section{Data and operationalization}

\subsection{PISA 2006}

Since 2000, the OECD has tri-annually conducted large-scale tests among 15-yearolds living in its member states and partner states in order to assess students' mathematical, reading, and scientific literacy. The purpose of this test is to map the competences in the fields of mathematics, physics and reading at the end of the period of compulsory education (at the age of 15 or 16 in most Western countries). We make use of the 2006 wave. The PISA data for each participating country constitute a representative sample of the schools that teach 15year-old students. Each school that has been selected tests a sample of all 15-year-olds, irrespective of their track or grade. In addition to educational performance, PISA also supplies information on a large number of individual background characteristics and school characteristics. The school principals provide details on a variety of school characteristics, such as student-teacher ratio, teacher shortages and the location of the school. In the student questionnaires, students are asked for information on such things as the educational level of their parents, the availability of resources at home, the language spoken at home and the country in which their parents were born. Considering the fact that the information on the country of origin of both parents is crucial for our research question, we can only include countries that have actually provided information on these countries of origin. Although no fewer than 57 countries took part in PISA 2006, only the following 15 Western countries had this information available: Australia, Austria, Belgium, Denmark, Finland, Germany, Greece, Latvia, Liechtenstein, Luxembourg, New Zealand, Norway, Portugal, Scotland and Switzerland. ${ }^{\text {iv }}$ The selection leaves us with 8,581 immigrant students from 35 different countries of origin, living in 15 Western destination countries ${ }^{\mathrm{v}}$ and all 72,315 native students in these 15 Western countries. Descriptive statistics can be found in appendix A. For a detailed description of the data and performance scores of the students from the different countries of origin, we refer to previous publications (Dronkers, 2010a; Heus \& Dronkers, 2010).

\subsection{Schools and tracks-within-schools as separate units of analysis}

The PISA data contain two cross-national indicators of the track the students are attending. The student is asked whether he or she is currently enrolled in a certain track of a certain level. This was later recoded in the international format distinguishing between general and vocational tracks on the one hand and between lower and higher tracks on the other hand. This recoding by the National PISA data managers probably reflects the official national policy regarding the placement of different tracks into the International classification. We can see this clearly by comparing for instance Finland and Scotland in appendix B: the 15-year-old students in Finland all attend lower general education while their counterparts in Scotland all attend higher general education. There was no other information available in the PISA data to differentiate this coding any further to make it more comparable. The same held for Germany where all students with a general track were coded at the lower level. But the 
national specific program code in the PISA data for Germany allowed us to distinguish between those students of general lower education with and without access to higher secondary education and between lower and higher vocational education (see appendix B). For the other countries this was not possible. As a general result, the level of "noise" in the measurement of the real track-level will increase and therefore underestimate the "real" tracklevel effect. This should be kept in mind when looking at the results of track-level effects. ${ }^{\mathrm{vi}}$

Schools are the sampling unit in the PISA survey. But these schools often contain both general and vocational education and both levels within secondary education. The schoollevel therefore reflects more the administrative unit of the educational institution, while the combined two track characteristics reflect more the daily reality of the teaching and learning environment, and also of the social intercourse between students and teachers. This daily life unit is a better indicator of the actual school environment of teaching and learning than the administrative unit. We call this the track-within-school-level. We compute this level per country for each student by combining his or her school identification number, the kind of track he or she is following (vocational or general), and the track-level (lower or higher). The result of this redefinition of school environment from an administrative unit into the daily life unit of teaching and learning is visible in appendix B. For example in Australia 345 schools offered lower general education, 133 schools higher general education and 10 schools higher vocational education for more than 5 students per school. In order to avoid extreme results for combinations with few cases, we deleted all combinations of school identification number, vocational or general education, and the track-level, which had less than 6 students per school. This means that the analysis will be based on 8,521 immigrant students from 35 different countries of origin, living in 15 Western destination countries and 72,329 native students in 15 countries.

\subsection{Dependent variable: linguistic performance}

The dependent variable in this study is linguistic performance. To measure linguistic skills accurately would make the test too long to be feasible. Hence a large number of very similar, but shorter tests were created. As such different tests can never have exactly the same degree of difficulty, Item Response Modelling (IRM) was used to achieve comparable results between students who made different tests. In this analysis, we averaged the five plausible values that were obtained from the IRM. The linguistic skills scores were standardised for the OECD countries using an average of 500 and a standard deviation of 100. Appendix C shows the average literacy scores for immigrant students for the origin and destination countries. Appendix E shows the outcomes if the dependent variable would be mathematical literacy or science literacy. The results indicate that the conclusions do not change much if we would take another dependent variable.

\subsection{Individual-level variables of all students}

Parental ESCS. The Index of economic, social and cultural status of the parents (ESCS) is a composite index created in the PISA dataset of the occupational status of the parents measured with the ISEI scale (Ganzeboom, De Graaf, Treiman \& De Leeuw, 1992), the educational level of the parents measured with the ISCED classification (UNESCO, 2006), and the presence of any material or cultural resources at the students' homes. ${ }^{\text {vii }}$ This combination of the parents' occupational status and educational level, together with the resources at home, produces the strongest indicator of the parental environment. We set the average of parental ESCS for each destination country to zero, to ensure that the comparisons for this item show the result for the average student in these countries. 
Grade. Since not all students attend the same grade, we have included a variable to account for this. As a result of between-country variance in the way grades are costructed, we have standardized the grade around the modal grade in a country.

Female. We control for gender effects by using a dummy variable indicating whether a student is female (1) or male (0).

\subsection{Individual-level variables of immigrant students}

Regions of origin. On the basis of earlier analyses of PISA 2003 data (Levels \& Dronkers, 2008; Levels et al., 2008), we combined the countries of origin in five regions of origin in order to simplify the presentation of the analysis: 1. Eastern Europe (Albania, Belarus, Bosnia, Croatia, Czech Republic, Estonia, Hungary, Macedonia, Poland, Rumania, Russia, Serbia \& Montenegro, Slovakia, Slovenia, Ukraine); 2. non-Islamic Asia (China, India, Korea, Philippines, Vietnam); 3. Islamic countries (Albania, Bangladesh, Morocco, Pakistan, Turkey); 4. Western OECD countries (Australia, Austria, Belgium, Denmark, France, Germany, Greece, Italy, Netherlands, New Zealand, Portugal, Spain, Sweden, Switzerland, United Kingdom, United States); 5. Sub-Sahara Africa (Cap Verde, Congo, South Africa). ${ }^{\text {viii }}$

Second generation migrant. In line with Rumbaut (2004), we have constructed immigrant generation variables that combine information on the country of birth of both parents and the student. Second generation immigrant children are those students of whom at least one parent was born abroad, but who have been born in the current country of destination themselves. First generation immigrant students have been born abroad themselves as well. A dummy indicates whether the student is second generation (1) or not (0).

One parent migrant, other parent native. A dummy variable was used to identify students who had one immigrant and one native-born parent (1); students with two non-native parents represent the reference group (0).

Home language same as in destination country. We included a dummy variable to differentiate immigrant children who speak one of their destination country's official languages at home (1) from children who speak a foreign language (0).

\subsection{Variables measured at the tracks-within-schools-level}

Vocational. A dummy variable indicates whether a student is currently enrolled in a (pre-) vocational (1) or general (0) type of education (ISCED classification).

Higher secondary. This dummy distinguishes the current track-level within secondary education as higher secondary (1) or lower secondary (0).

Ethnic diversity. Using the numbers of students from all 35 countries of origin, we calculated the Herfindahl index of ethnic diversity per track-within-school (varying between 0 and 1). ${ }^{\text {ix }}$ Every 35 countries of origin here represented a separate ethnic group, also the native students. ${ }^{\mathrm{x}}$ The index should be interpreted as follows: the value 0 means that there was no ethnic diversity at all in the school, because all students came from the same country of origin. Values that approach 1 represent a very high degree of diversity: the students at that track-within-school are equally recruited from all origin countries, including the home country. The Herfindahl index has been criticised for being 'colour-blind' (Stolle, Soraka \& Johnston, 2008; Voas, Crockett \& Olson, 2002), which means that a school with $20 \%$ Turkish students and $80 \%$ native students, obtains the same diversity score as a school with $20 \%$ native students and $80 \%$ Turkish students. The specific ethnic composition of the trackwithin-school is therefore also important, and hence we used appropriate indicators (see below). 
ESCS diversity. In a similar way, we calculated the socio-cultural diversity of the tracks-within-schools. Using the ESCS scores of the parents we divided these parental scores in 5 categories; the group with the lowest $10 \%$ scores, the $10-30 \%$ group; the $30-70 \%$ group; the $70-90 \%$ group and the group with the highest $10 \%$ scores. ${ }^{\mathrm{xi}}$ On the basis of these 5 categories we calculated the Herfindahl index of socio-cultural diversity (varying between 0 and 1). ${ }^{\text {xii }}$ The index should be interpreted as follows: a value 0 means that there is no diversity, because all parents of all students at that particular track-within-school are in the same ESCS category. A value approaching 1 indicates a very high level of diversity, indicating that the students are equally recruited from the five ESCS categories. As this Herfindahl index of socio-cultural diversity is "level-blind" and therefore insensitive to the average parental educational level, we have also added the average ESCS of a school to the analysis (see below).

Percent students from immigrant regions. As indicated above the countries of origin were combined into five categories in order to simplify the presentation of the analysis. For each track-within-school, we calculated five indexes: the percentage of students from Eastern Europe; the percentage of students from non-Islamic Asia; the percentage of students from Islamic countries; the percentage of students from Western OECD countries; and the percentage of students from Sub-Sahara Africa. These indexes are the necessary counterparts of the Herfindahl index of ethnic diversity, which after all is "colour-blind”. Together, these indexes measure the combined effect of ethnic diversity and ethnic share.

Average ESCS. We also calculated the average parental ESCS per track-within-school. This index is the necessary counterpart of the Herfindahl index of socio-cultural diversity, which is "level-blind". Together, these indexes measure the combined effect of socio-cultural diversity and socio-cultural share.

\subsection{Variables measured at the school-level}

Selective admittance of students to the school is a scale in the PISA data based on the answers of the principals indicating whether admittance to their school was based on academic record and/or on recommendation. We divided the scale in three dummies: selective admittance, some selection and no selection. Although these dummies are measured at the school-level, we use them to control the amount of entrance selectivity at the track-level.

Teacher shortage. The degree in which schools suffer a shortage of teachers is an index in the PISA data which indicates according to the principals to what extent education is hampered by the following items: a lack of qualified physics teachers, a lack of qualified mathematics teachers, a lack of qualified language teachers and a lack of qualified teachers for the other subjects. This index is based on the answers given by the school principals. The average of this index for teacher shortage was set to zero for all destination countries and all students, to ensure that the comparisons for this item show the result for the student in schools with an average shortage of teachers.

Student-staff ratio. The student-staff ratio (the number of students per member of staff per school) is based on the answer given by the school principals. The average for this ratio was set to zero for all destination countries and all students, to ensure that the comparisons for this item show the result for the students in schools with an average student-staff ratio.

Urbanisation. Two dummies were constructed to indicate whether a school is located in a (large) city or in a rural area. Schools in an urbanized countryside or in (small) towns serve as the reference category.

Schoolsize. Number of students in the school.

Private public. Educational systems differ in the shares of public and private schools and in the degree of state grants for these private scores. Two dummies were constructed to separate private dependent and private independent schools from public schools. These 
variables control for these system differences and effectiveness of these school-types (Dronkers \& Avram, 2010a and 2010b).

\subsection{Variables measured at the country-level}

Stratification. To measure the level of differentiation of the educational system, we classified countries according to their stratification level. We define Austria, Switzerland, Germany and Liechtenstein as highly stratified systems; Belgium, Greece, Portugal, and Luxembourg as moderately stratified systems; and Finland, Norway, Denmark, New Zealand, Australia, Scotland, and Latvia as comprehensive educational systems that are hardly stratified. Our division is based on information on the first age at which students have to choose between different educational types, the number of school-types students can choose between, and the presence of more hidden types of ability grouping (Heus \& Dronkers, 2010; OECD, 2007). In the highly stratified countries, children can choose between at least 3 different educational types at age 10 (Germany, Austria), 11 (Liechtenstein), or 12 (Switzerland). In comprehensive systems, children are not tracked into different educational types before age 15. We use dummy variables indicating whether countries have highly stratified, moderately stratified or comprehensive education systems.

Age of selection. Apart from these three dummies, age of selection is included in the analysis.

\section{Models}

The multilevel analyses are done separately for natives (table 1) and immigrant students (table 2). ${ }^{\text {xiii }}$ The multilevel analysis for the immigrant students uses cross-classified multilevel regression analyses (Snijders and Bosker, 1999; Tubergen 2005), because the countries of origin and destination cannot be structured hierarchically. Because of the maximum of 5 levels in MlWin, we could not use schools as a separate level above the trackwithin-schools level. A cross-classified analysis for immigrant students needs, apart from the four levels for pupils, tracks, schools and destination countries, two more levels, one for the origin countries and the other for the cross-classified identification. However, six levels are impossible in MlWin. Therefore this multilevel analysis has three hierarchical levels: countries of origin/destination, track-within-schools and students. School characteristics are thus transferred to the tracks-within-schools level. The multilevel analysis for the native students does not need a country of origin level. Therefore we could use four hierarchical levels: countries, schools, tracks-within-schools and students.

\section{Models}

The models in both multi-level analyses are the same. Model 0 is the empty model, which indicates how much variance is situated at the different levels. This model is important because it shows that a relatively large amount of variance is related to the track-withinschools level, underlining the importance of the distinction between schools and trackswithin-schools (see table 1 and 2). It also shows that a larger amount of variance is related to the country of origin than to the country of destination, underlining the importance of including the countries of origin for explaining achievement differences among immigrant students (see table 2).

Model 1 includes the individual characteristics and the educational system characteristics, plus the interactions between the latter and parental ESCS. Model 1 resembles thus the standard approach to the analysis of educational systems effects, with country-level characteristics directly affecting educational performance. The only difference is that this model already contains the other distinguished levels like the tracks-within-schools level, the 
school-level and/or the origin country-level. In order to estimate the relevance of our approach, we present in Appendix D the same model 1 and the same data but with only 2 levels: students and countries. The omission of the school- and tracks-within-schools-levels increases the amount of variance at the individual-level and at the country-level. Also the parameters of the individual variables tend to be stronger in a two-level model than in a comparable four-level model. Especially the effects of parental ESCS are larger in a two-level approach than in the more correct four-level approach. Moreover the interactions between parental ESCS and educational systems characteristics are smaller in a two-level approach than in the more correct four-level approach. This is true both for native and immigrant students, if we do not take into account the immigration history variables and the origin countries.

Model 2 adds some social and ethnic composition variables at the track-within-schoollevel: the shares of immigrant students, the average parental ESCS, the ECSC- and ethnic diversity and two interaction terms between educational system and average parental ECSC to the equation of model 1 . This model assumes that most of the variance at the school- or trackwithin-schools-level is related with the social and ethnic school-composition and not with differences in the curriculum of the track. Model 2 comes closest to the approach of Dunne (2010), who introduced for the first time a school-level between the educational system-level and the students-level.

In model 3 we add the curriculum characteristics of the track (vocational orientation of the track; the level of the track; and two dummies regarding selective admittance although these dummies are measured at the school-level) as well as the interaction between the level of the track and the stratification of the educational system to the equation of model 1 . This model assumes that most of the variance at the school- or track-within-schools-level is related with differences in the track and not with the social and ethnic school-composition.

Model 4 combines models 2 and 3 by adding the social and ethnic composition variables as well as the curriculum characteristics of the track. The results for model 4 show that both aspects (composition and curriculum characteristics of the track) need to be included in the analysis in order to get a better fit with the data. Also the parameters of composition and curriculum variables are significant in this combined inclusion in the equation. This model best reflects our new approach of including curriculum characteristics next to characteristics of the students, the social and ethnic school-composition and characteristics of the educational system.

In models 5 and 6 we add more school variables and interactions to the equation of model 4 in order to make sure that the results of model 4 are not biased by the omission of these variables and interactions. These additions do not substantially alter the results of model 4.

\section{Main results}

$<$ tables 1, 2 and 3 about here $>$

Table 1 presents the outcomes of the different models for the native students while table 2 presents the outcomes for the immigrant students. Table 3 summarizes some of the main results of the outcomes of model 6 in tables 1 and 2, especially the different effects of parental ESCS, ECSC school-composition and track-level in the three educational systems. The scores for immigrant students in table 3 pertain to first generation immigrant students from Western OECD countries whose home language is not the same as in the destination country and who have two non-native parents. The scores of the immigrant students from Eastern Europe, non-Islamic Asia, Islamic countries and Sub-Saharan African countries can be found by changing these scores with $-8.2,+18.6,-35.3$ and -15.0 respectively (see model 6 , 
table 2). The scores of second-generation immigrant students can be found by increasing these scores with +9.3 , of those who use the same language as the destination country with +24.2 and those with mixed parents with +5.8 (see model 6, table 2).

\subsection{The different importance of tracks in different educational systems}

Our first hypothesis assumes that track-levels explain a substantial part of the effect of ESCS school-composition on achievement, but mostly in highly stratified educational systems, due to the institutionalized borders in these systems. If we compare the log likelihood of model 4 in tables 1 and 2 with that of model 2 (only school-composition) and model 3 (only curriculum characteristics) we see that the log likelihood is lower in model 4 than that in models 2 and 3 for both populations. This supports our first hypothesis that tracklevel explains a substantial part of the school-composition effect and that the effects of curriculum characteristics should be distinguished from the effects of school-composition. But compared with the log likelihood of model 1 (only individual characteristics) the addition of school-composition (model 2) lowers the log likelihood more than the addition of curriculum characteristics (model 3). This means that school-composition can better explain variance in educational performance than the curriculum characteristics in both populations. Furthermore, it is interesting to note that school-composition - although defined at the trackwithin-school-level - explains as much of the school-level variation as of the track-withinschool-level variation (see model 2 in table 1), while the curriculum variables only explain track-within-school-level variation. This seems to suggest that the school-composition is as much a school-characteristic as it is a track-within-school characteristic. In other words, school-composition varies as much between schools as within schools between track-levels.

The interaction terms between track-level and strongly or moderately stratified educational systems are positive and significant for both populations, in accordance with the first hypothesis. It means that for the higher level there is less difference between the educational systems. The main differences occur at the lower level. To illustrate: for native students at the low level the difference between moderate and comprehensive systems is 45,5 to the advantage of the comprehensive system (model 3 in table 1), while for the higher level this has changed into a slight positive advantage for the moderate stratified systems of $+14,4$ $(-0,6-45,5+59,3)$. For immigrant students these figures are $-41,1$ and $+7,5$ respectively. Interestingly the interaction term between track-level and moderately stratified educational systems is stronger than the interaction term between track-level and strongly stratified educational systems at least for native students. For immigrant students both interaction terms are more or less the same.

\subsection{The different importance of ESCS school-composition in different educational systems.}

Our second hypothesis assumes that the positive effect of ESCS school-composition on achievement is strongest in highly and moderately stratified systems, because ESCS school-composition indicates both the level of the curriculum and ESCS neighborhoodcomposition, while ESCS school-composition in comprehensive educational systems indicates only differentiation in ESCS neighborhood-composition. Model 2 in tables 1 and 2 (only school-composition) shows that ESCS school-composition has strong effects on educational achievement, both for native and immigrant students in all systems, but much stronger in the moderately (both groups) and highly (only immigrants) stratified systems than in the comprehensive systems (positive effects of the interaction terms). However, after the inclusion of the curriculum variables (model 4 in tables 1 and 2) these interaction effects are strongly reduced and become insignificant in three out of four cases. This indicates that part of the observed effect of the ESCS school-composition is due to curriculum effects in accordance with our second hypothesis. The only remaining effect of ESCS school- 
composition is for immigrants in highly stratified systems. This suggests that the strong results of Dunne's (2010) of school-composition were partly caused by the fact that she did not include the track-level in her analyses.

\subsection{The different importance of individual ESCS in different educational systems.}

Our third hypothesis assumes that the effect of individual ESCS on achievement is stronger in comprehensive systems. The lack of selection into hierarchical track-levels forces higher-class parents to use their cultural and social capital more to ensure sufficient schoolperformance at the end of secondary school. Tables 1 and 2 show that individual ESCS has strong effects on educational achievement, both for native and immigrant students. These individual ESCS effects tend to be a little bit larger for the native students than for the immigrant students (see table 3). Individual ESCS of immigrants might be a less good indicator of their resources (ability, social, cultural) than for native parents. Also the positive selection of immigrants due to the obstacles and challenges of migration might be an explanation of this lower effect of individual ESCS on achievement of immigrant students (Feliciano, 2005; Dronkers \& Heus, 2010a).

The same table 3 also shows that the effects of individual ESCS is weaker in moderately and strongly stratified educational systems for native and immigrant students, in accordance with our third hypothesis and Dunne's (2010) results. Thus, her results cannot be explained by her omission of track-level in her analyses.

\subsection{Immigrants and educational systems.}

Our fourth hypothesis assumes that students with an immigrant background have the highest achievement in either strongly stratified systems, because these provide them with clear information about their scholastic requirements or in comprehensive educational systems, because they do not have institutionalized curriculum borders which precludes high educational performances. The results of table 3 support this expectation only for the comprehensive educational systems, but not for strongly stratified systems. The achievement score of Western OECD first generation immigrant students is largest in comprehensive systems (457.7) while their scores in the other two educational systems are slightly (but not significant) lower (441.0). In contrast the achievement score of native students is highest in comprehensive systems (483.4) and lowest in moderately stratified systems (466.6). The achievement differences between Western OECD first generation immigrant students and native students are smallest in comprehensive (483.4 - $457.7=25.7)$ and moderately stratified systems $(466.6-441.0=25.6)$ and largest in strongly stratified systems $(481.5-441.0=$ 40.5). It is also interesting to note that the effect of ESCS school-composition in strongly stratified systems is larger for Western OECD first generation immigrants' than native children (63.2 versus 43.5) but that in moderately stratified system this difference in effect of ESCS school-composition is smaller (35.9 versus 52.5).

As indicated above, the scores for immigrant students in table 3 pertain to first generation immigrant students from Western OECD countries whose home language is not the same as in the destination country and who have two non-native parents. The scores for the other immigrant groups can be found by simply adding or distracting the relevant parameters from model 6 in table 2. But this does not change the different outcomes for the different educational systems.

However, these results are only true for the average students, not for various subgroups. Table 4 gives the estimated reading scores for students with the lowest and highest parental ECSC scores in schools with the lowest and highest average ECSC schoolcomposition in the three educational systems for both natives and Western OECD first generation immigrants. ${ }^{\text {xiv }}$ The results indicate that students from high ESCS parents perform 
best in schools with a high ESCS composition in comprehensive systems. This result holds for both native and Western OECD first generation immigrant students and for all tracks (vocational lower, general lower and general higher). These students perform worst in schools with a low ECSC composition in moderately stratified systems (natives) or strongly stratified systems (immigrants). The situation is quite different for the students with low ECSC parents. They perform best in schools with a high ESCS composition in moderately stratified systems (natives) or strongly stratified systems (immigrants). And they perform worst in schools with a low ECSC composition in comprehensive systems. This result holds again for all tracks (vocational lower, general lower and general higher). In other words: students from different ESCS backgrounds do not have the same educational opportunities and constraints in the different educational systems. A generic educational policy for these different groups might therefore produce different outcomes for students from low and high ECSC parents. Interestingly the educational outcomes for immigrant and native students with comparable ESCS background are more alike.

\subsection{Reproduction}

Our fifth hypothesis assumes that the interaction effect of individual ESCS and ESCS school-composition on achievement is positive and equal in all educational systems, because this combination of individual and school-composition ESCS is an indicator of a higher level of unmeasured cultural and financial capital of parents and schools. The basic idea is that individual and school ESCS reinforce each other, which will show up in a positive interaction term. Model 6 in tables 1 and 2 shows that this hypothesis is not supported by our analysis, neither for the native nor for the immigrant students. The opposite seems more correct: the interaction is negative and significant for native students. This negative effect might result from measurement errors in the individual indicators but also from regression-to-the-mean. Although this result does not directly invalidate the reproduction theory, it does invalidate some of their strong claims like the reinforcement effect.

\section{Conclusions}

\subsection{The importance of school- and track-level.}

The first conclusion of this paper is that an analysis of educational systems effects is flawed if it uses only a country- and a student-level. Additional school-and and track-withinschool-level is necessary in order to get reliable estimators of system- and individual-effects. Appendix D shows that the omission of the school- and track-within-schools-levels increases the amount of variance at the individual-level and at the country-level compared with fourlevel models. Also the effects of the individual variables tend to be stronger in a two-level model than in a comparable four-level model. Especially the effects of parental ESCS are larger in a two-level approach than in the more correct four-level approach. Moreover the interactions between parental ESCS and educational systems characteristics are smaller in a two-level approach than in the more correct four-level approach. That is true both for native and immigrant students. Finally the fit of four-level models is far better than that of two-level models, which indicates that a two-level model gives a less adequate description of the relations between educational systems and educational achievement than a four-level model. As a consequence the outcomes of two-level models, which are still dominant in the study of effects of educational systems, are flawed.

\subsection{Partial confirmation of the earlier results by Dunne (2010).}

Our analysis confirmed the results of Dunne (2010) on the differential effects of parental background in different educational systems. The direct effect of parental ESCS is 
strongest in comprehensive systems, and smaller in moderately and strongly stratified educational systems, also after inclusion of the track-level within the schools, the origin countries of immigrant students and the ethnic school-diversity.

However, Dunne's results on the effects of the average school ECSC are not confirmed. Without control for curriculum characteristics the effects of average school ECSC are significantly larger in more stratified systems for both populations. After control for curriculum characteristics however, the effects of average school ECSC in more stratified systems are no longer significant for the native population and only significantly larger for immigrant students in strongly stratified systems.

\subsection{Different effects of curriculum}

The inclusion of the track-level is necessary to avoid overestimation of the schoolcomposition effect, especially in stratified educational systems. Our results show that the effect of the track-level is absent in comprehensive educational system, while the effect is significant and positive in all stratified educational systems. In other words, the level of the curriculum makes sense in stratified educational systems. Table 3 shows the consequences of this distinction between track-levels. In a comprehensive system, the average reading score for native students is 483 for students at the lower track-level and 479 at the higher level. Note that the fact that there is no difference between the higher and lower level in the comprehensive system is a result of the fact that countries code their system differently (see section 3). In moderately stratified systems the scores are 467 and 488 and in strongly stratified systems 482 and 489. Attaining the higher track-level is thus important for educational achievement in the stratified systems. Not taking the track-level into account will give biased and flawed outcomes in analyses of effects of educational systems and schoolcomposition. The table shows that no educational system can claim to have the best results for all students, but that the results differ for natives and immigrants and for the track-level. For the native students at the lower track-level the best results are obtained in either the comprehensive or the strong stratified systems. For the immigrant students at this level the comprehensive system is clearly superior to the two others. For students at the higher level the situation is clearly different. The native students at this level have the highest achievements in the strong or moderately stratified systems, while the immigrant students get the best results only in the moderately stratified systems.

\subsection{A negative effect of vocational education?}

Students with a vocational oriented curriculum have lower reading scores than students in a general oriented curriculum, and it is not easy to explain that lower score by the social and cultural characteristics of these students, their schools or educational systems. Despite all control variables in model 6 of tables 1 and 2, students with a vocational oriented curriculum score 54 (immigrants) and 52 (natives) point lower than students in a general oriented curriculum. Appendix E shows that the differences in scores between students with a vocational oriented curriculum and students in a general oriented curriculum for math and science are more or less the same. These equal differences do not support their explanation as a consequence of a choice between more technical and cultural preferences and/or abilities of students. A possible explanation of these equal differences is that students in the general and vocational curriculum differ strongly in scholastic ability, and for that reason differ strongly on all school-tests, irrespective of their content (Rindermann \& Ceci, 2009). Further analyses (not shown here) indicate that these lower scores of students with a vocational oriented curriculum occur in all educational systems, but that in moderately stratified systems these students score around 35 points lower than in the other systems (both populations). 


\subsection{Direct and indirect effects of parental background}

The direct effects of parental ECSC on reading scores are smaller in moderately and strongly stratified educational systems than in comprehensive systems. But the bivariate correlations between parental ECSC and reading scores are more or less equal in the three systems: natives $0.33,0.36,0.37$; immigrants $0.36 ; 0.35 ; 0,39$. The analogous partial correlations, controlled for ECSC school-composition, are 0.22, 0.11, 0.10; and 0.23, 0.14 and 0.16 respectively. This difference between the bivariate correlations and partial correlations can be explained by the different bivariate correlations between parental ECSC and ECSC school-composition in the three educational systems: natives $0.48,0.54,0.61$; immigrants 0.47, 0.48, 0.49. In other words: the influence of parental ECSC on the selection of students into different tracks and schools is higher in stratified systems, because the long-term consequences of that selection are more severe than in comprehensive systems where there is no selection. Without having passed that selection into different schools and tracks the influence of parental ECSC is larger in comprehensive systems because the effect of social background has not yet been transformed into different tracking or ability grouping.

\subsection{The effects of origin for immigrant students and educational systems}

Estimates of effects of educational systems will be flawed if they do not take into account the different origin countries of immigrant students in different destination countries and the different levels of ethnic school-diversity in different destination countries. By not taking into account the countries of origin of immigrant students the positive effects of comprehensive systems will be overestimated because the Scandinavian countries with comprehensive systems have relatively few immigrant students originating from Islamic countries. Also the negative effects of strongly stratified systems will be overestimated by the non-inclusion of origin countries because Austria, Germany, Liechtenstein and Switzerland have relatively many immigrant students originating from Islamic countries. These flaws are made in influential OECD reports like Where Immigrant Students Succeed; A Comparative Review of Performance and Engagement in PISA 2003 (OECD, 2006), despite the fact that origin country is already available in PISA 2003.

Immigrant students originating from Islamic countries have a lower educational achievement than equivalent immigrant children, originating from other countries. Multiple explanations may be proposed: a discriminating attitude towards immigrant students from Islamic countries; negative selectiveness of guest worker programmes, where most guest workers in Europe came from Islamic countries; values and standards of the current Islam which are less suitable for success in modern societies (honour, unequal gender roles). André, Dronkers and Fleischmann (2009) have used data from the European Social Survey (ESS) ${ }^{\mathrm{xv}}$ to show that the degree of subjective feelings of discrimination of immigrants in the EU with an Islamic religion is not greater than of Greek Orthodox or Jewish believers. Dronkers and Heus (2010a) have shown that the negative selectiveness of immigrants from Turkey is not greater than that from non-Islamic guest worker countries (Yugoslavia, Italy, Portugal). Dronkers and Fleischmann (2010) have shown on the basis of the same ESS data that second-generation male Islam believers in Europe obtain a lower educational level than comparable immigrants with different religions. We have also shown that the Islamic faith of individual immigrants leads to a lower educational level, not the fact of originating from a country with an Islamic majority.

Immigrant students originating from Non-Islamic Asian countries have higher educational achievement than equivalent immigrant children, originating from other countries. The standard explanations for this advantage (working harder for education; authoritarian education system; the "ideal immigrant") do not stand up empirically (see Dronkers \& Heus, 2010b). Asia is therefore a much greater challenge for Europe in the field 
of education than the US (see also Dronkers, 2010b). These earlier results are not changed by the improved measurement of the concrete school-environment and its characteristics by the track-within-school-level.

\subsection{Negative effect of ethnic school-diversity in different systems and populations}

Ethnic school-diversity has a negative effect on achievement scores, but only for immigrant students, not for natives. However, analyses (not shown here) show that the negative ethnic school-diversity effect for native students is significant in strongly stratified system and insignificant in the two other systems. The negative ethnic school-diversity effect does not vary between educational systems for immigrant students. This result partly contradicts the earlier outcomes by Dronkers (2010a) who found significant negative effects for both populations in moderately and strongly stratified educational systems. The most plausible explanation of this difference is the more relevant measurement of the ethnic diversity at the track-within-school-level instead of at the school-level. Measuring ethnic diversity at the school-level might pick up ethnic diversity between tracks instead of ethnic diversity within tracks. The improved measurement of the concrete school-environment and its characteristics by the tracks-within-school-level is only relevant for the more stratified systems. But regardless of the educational system, ethnic school-diversity has a negative effect on the educational performance of immigrant students, a result already found by Dronkers (2010a). The improved measurement of the concrete school-environment and its characteristics by the tracks-within-school-level has not changed that result.

\subsection{No effect of ESCS school-diversity}

ESCS school-diversity has no negative effect. ESCS school-diversity has only a positive significant effect in moderately stratified systems for immigrant students (additional analysis not shown here). ESCS school-diversity does not seem to be such an important factor for the improvement of educational performance, as sometimes suggested by policy-makers and educationalists.

\subsection{Caveats}

Finally we want to make two caveats in relation with our results. The first is a consequence of the need to control for the origin countries of the immigrant students in order to get a more correct estimation of the effects of educational systems. Doing so requires the inclusion of more destination countries, both inside and outside of Europe. Important countries to take into account would for instance be Canada, England, France and the USA. Only 16 of the OECD countries participating in PISA 2006 have asked sufficiently detailed information about the country of birth of students and their parents and very few additional countries have done that in PISA 2009. This is not only a drawback for the scientific analysis of the educational achievement of immigrant students, but it is also socially and politically irresponsible to deny or ignore the importance of origin countries (see for instance EU Commission, 2008).

The second caveat is that the quality of the measurement of the level of the track students attend needs to be improved especially for countries with comprehensive educational systems (compare the levels of Scotland with that of Finland). Also the internal differentiation within schools (track, streams, etc) should be measured better. 


\section{Notes}

${ }^{\mathrm{i}}$ If they are omitted from the analysis, the results might be misleading (Swedish and Russian immigrants in Finland with a comprehensive system and Turkish and Yugoslav immigrants in Germany with a strongly differentiated system can not be treated as the same immigrants, even after control for all measured background characteristics).

${ }^{\text {ii }}$ This section is primarily based on Dunne (2010).

${ }^{\mathrm{iii}}$ We could not use the same countries because a number of them collected no information about the countries of birth of the students and their parents.

${ }^{\text {iv }}$ The question on country of birth was not asked in a similar way in all countries. Most countries asked the country of origin for the main immigrant groups in the country concerned. In the German questionnaires, possible countries of origin were therefore: Russia, Former Yugoslavia, Greece, Italy, Poland and Turkey, while the Scottish questionnaire listed the options China, India, the Middle East, Africa, the Caribbean, and Europe. See also Levels, Dronkers \& Kraaykamp (2008).

${ }^{v}$ As PISA allows participating countries to determine the country of origin categories themselves, the level of detail differs among countries. As a result, the countries of origin that we have identified are dependent on the quality of the answer categories. To take this into consideration, we have compared the countries of origin that we defined with national statistics. In the case of Australia, Austria, Finland, Luxembourg, New Zealand and Switzerland, the three main groups of immigrants as listed by their national statistics, match countries of origin that we found. In the case of Belgium, Germany, Liechtenstein and Scotland, the two main groups as indicated by their national statistics, match the countries of origin identified by us. In Greece, the main group of foreign origin consists of Albanians (42 percent of all immigrants, Eurostat, 2008), and this also matches our data. The main group of foreign origin in Latvia concerns Russians (35 percent of all immigrants, Eurostat, 2008), and this is also reflected in our data.

${ }^{\mathrm{vi}}$ We also checked whether centering the track-level per country would solve this problem. The centered values are displayed in the last column of appendix B and the results of using centered values instead of the measured track-levels are shown in appendix F. In general the results do not change much, which is the reason why we decided to use the original track-levels.

${ }_{\text {vii }}$ The measure consists of the presence of a desk, a private room, a quiet place to study, a computer, educational software, Internet, literature or poetry, art, books that may be of use when doing schoolwork, a dictionary, a dishwasher, and the presence of more than 100 books in the house.

viii The number of immigrants' children from Latin America is too small to justify a separate region.

${ }^{\text {ix }}$ The Herfindahl index of ethnic diversity was calculated as follows: $1-\left((\text { percentage of ethnic group } 1)^{2}+\right.$ (percentage of ethnic group 2$)^{2}+\ldots+(\text { percentage of ethnic group } n)^{2}$ ).

${ }^{\mathrm{x}}$ For the computation of the ethnic diversity we used the countries of origins, not the regions of origins.

${ }^{\mathrm{xi}}$ The groups are defined as follows: 1 . Less than 10\%: ESCS $<=-1.1 ; 2.10-30 \%:-1.0<$ ESCS $<=-0.4 ; 3$. 3070\%: $-0.3<$ ESCS < =0.6; 4. 70-90\%: $0.7<$ ESCS $<=1.2$; 5. more than 90\%: ESCS $>=1.3$.

${ }^{x i i}$ The Herfindahl index of socio-cultural diversity was calculated as follows: 1 -((percentage of parents from ESCS group 1$)^{2}+(\text { percentage of parents from ESCS group } 2)^{2}+\ldots+($ percentage of parents from ESCS group 5) ${ }^{2}$ ).

${ }_{\text {xiii }}$ The separate analysis of the native and immigrant students is already a departure of the standard approach, which does not distinguish between these students, despite the fact that they are unequally distributed among the countries in the analysis.

${ }^{\text {xiv }}$ For an overview of the underlying parameters, see appendices $\mathrm{G}$ and $\mathrm{H}$.

${ }^{\mathrm{xv}}$ The ESS contains information about the individual religion of the respondents. 


\section{Literature}

Ammermuller, A. (2005), Educational Opportunities and the Role of Institutions, ZEW Discussion Papers, 44.

André, S., Dronkers, J. \& Fleischmann, F. (2009), Verschillen in groepsdiscriminatie, zoals waargenomen door immigranten uit verschillende herkomstlanden in veertien lidstaten van de Europese Unie [Differences in In-Group Discrimination as Perceived by Immigrants from Various Countries of Origin in Fourteen Member-States of the European Union], Mens en Maatschappij 84: 448-482.

Blau, P. M. \& Duncan, O.D. (1967), The American Occupational Structure, New York: The Free Press.

Bourdieu, P. \& Passeron, J.C. (1977), Reproduction in Education, Society and Culture, Sage Publications.

Breen, R. \& Jonsson, J.O. (2000), Analysing Educational Careers: A Multinomial Transition Model, American Sociological Review, Vol. 65(5):754-772.

Breen, R \& Jonsson, J.O. (2005), Inequality of Opportunity in Comparative Perspective: Recent Research on Educational Attainment and Social Mobility, Annual Review of Sociology Vol. 31:223-243.

Buchmann, C. \& Hannum, E. (2001), Education and Stratification in Developing Countries: A Review of Theories and Research, Annual Review of Sociology, Vol. 27:77-102.

Coleman, J.S. (1966), Equality of Educational Opportunity, National Center for Educational Statistics (DHEW/OE), Washington, DC.

Dronkers J. (2010a), Positieve maar ook negatieve effecten van etnische diversiteit in scholen op onderwijsprestaties? Een empirische toets met internationale PISA-data [Positive but also Negative Effects of Ethnic Diversity in Schools on Educational Achievement? An Empirical Test with Cross-National PISA-Data], Tijdschrift voor Onderwijsrecht en Onderwijsbeleid 6: 483-499. English version paper presented at the conference Integration and Inequality in Educational Institutions at the University of Bremen, Teerhof, 24-25 September 2010.

Dronkers, J., (2010b), Features of Educational Systems as Factors in the Creation of Unequal Educational Outcomes, In J. Dronkers (Ed.), Quality and Inequality of Education. Cross-National Perspectives, pp. 299-328, Dordrecht /Heidelberg/ London/ New York: Springer.

Dronkers, J. \& Avram, S. (2010a), A Cross-National Analysis of the Relations of School Choice and Effectiveness Differences between Private-Dependent and Public Schools, Educational Research and Evaluation, 16:151-175.

Dronkers, J. \& Avram, S. (2010b), A Cross-National Analysis of the Relations of School Choice and Effectiveness Differences between Private-Independent and Public Schools, Sociological Theory and Methods, 25: 183-206.

Dronkers, J. \& Heus, M. de (2010a), Negative Selectivity of Europe's Guest-Workers Immigration? The Educational Achievement of Children of Immigrants Compared with the Educational Achievement of Native Children in their Origin Countries, In: E. de Corte \& J. Fenstad (Eds.), From Information to Knowledge; from Knowledge to Wisdom: Challenges and Changes facing Higher Education in the Digital Age, pp. 89-104, London: Portland Press.

Dronkers, J. \& Heus, M. de (2010b), The Higher Educational Achievement of Chinese Pupils, inside and outside of Asia: the Higher Transparency of Chinese Numbers or a Higher Value of Learning within Chinese Culture? Unpublished manuscript.

Dunne, A. (2010), Dividing Lines: Examining the Relative Importance of between- and within-School Differentiation during Lower Secondary Education. Ph.D. European University Institute (Florence).

Dustmann, C. (2004), Parental Background, Secondary School Track Choice and Wages. Oxford Economic Papers 56(2).

European Commission (2008), Migration \& Mobility: Challenges and Opportunities for EU Education Systems. Brussels: Green Paper 
Erikson, R., \& Jonsson, J. O. (Eds.) (1996), Can Education be Equalized? The Swedish Case in Comparative Perspective, Boulder: Westview Press.

Feliciano, C. (2005), Educational Selectivity in U.S. Immigration: How Do Immigrants Compare to Those Left behind? Demography 42:131-152.

Filmer, D. \& Pritchett, L. (1999), The Effect of Household Wealth on Educational Attainment: Evidence from 35 countries, Population and Development Review Vol. 25:85-120.

Gamoran, A. (1992), Social Factors in Education, In: M. Alkin (ed.), Encyclopedia of Educational Research (6 $6^{\text {th }}$ ed.), pp.1222-1229, New York: Macmillan.

Gamoran, A. (2004), Classroom Organization and Instructional Quality, In: H.J. Walberg, A.J. Reynolds \& M.C. Wang (eds.), Can Unlike Students Learn Together? Grade Retention, Tracking, and Grouping, pp. 141-55. Greenwich, CT: Information Age.

Gamoran, A., Nystrand, M., Berends, M. \& LePore, P.C. (1995), An Organisational Analysis of the Effects of Ability Grouping, American Educational Research Journal. Vol.32 (4):687-715.

Ganzeboom, H. B. G., Graaf, P. de, Treiman, D. J. \& De Leeuw, J. (1992), A Standard International Socio-Economic Index of Occupational Status, Social Science Research, 21, 1-56.

Hanushek, E.A. \& Woessmann, L. (2006), Does Educational Tracking Affect Performance and Inequality? Differences-in-Differences Evidence across Countries, Economic Journal, Vol. 116 (510:C63).

Hargreaves, D (1967), Social Relations in a Secondary School, London: Routledge \& Kegan Paul.

Hauser, R. M. \& Sewell, W. H. (1986), Family Effects in Simple Models of Education, Occupational Status, and Earnings: Findings from the Wisconsin and Kalamazoo studies, Journal of Labor Economics. July 4 (Part 2) S83-S115.

Heus, M. de \& Dronkers, J. (2010a), De onderwijsprestaties van immigrantkinderen in 16 OECD-landen. De invloed van onderwijsstelsels en overige samenlevingskenmerken van zowel herkomst- als bestemmingslanden. [The Educational Performance of Immigrant Children in 16 OECD-countries. The Influence of Educational Systems and Other Societal Features of Both Countries of Origin and Destination], Tijdschrift voor Sociologie, 31: 260-294.

Hopper, E. I. (1968), A Typology for the Classification of Educational Systems. Sociology, 2:29-46.

Horn, D (2009), Age of Selection Counts: a Cross-Country Analysis of Educational Institutions, Educational Research and Evaluation, Vol. 15 4:343-366.

Jencks, C. (1972), Inequality: a Reassessment of the Effect of Family and Schooling in America, Harmondsworth: Penguin Books.

Jencks, C., Bartlett, S., Corcoran, M., Crouse, J., Eaglesfield, C., Jackson, G., McClelland, K., Mueser, P., Olneck, M., Schwartz, J., Ward, S. \& Williams, J. (1979), Who Gets Ahead? The Determinants of Economic Success in America. New York: Basic Books.

Kerckhoff, A.C. (1986), Effects of Ability Groups in British Secondary Schools, American Sociological Review, Vol. 51:842-858.

Kerckhoff, A.C. (1995), Institutional Arrangements and Stratification Processes in Industrial Societies, Annual Review of Sociology, Vol. 15:323-47.

Levels, M. \& Dronkers J. (2008), Educational Performance of Native and Immigrant Children from Various Countries of Origin, Ethnic and Racial Studies, 31:1404-1425.

Levels, M., Dronkers, J. \& Kraaykamp, G. (2008), Immigrant Children's Educational Achievement in Western Countries: Origin, Destination, and Community Effects on Mathematical Performance, American Sociological Review, 73:835-853.

Lucas, S.R. (1999), Tracking Inequality: Stratification and Mobility in American High Schools. Teachers College Press. 
Mare, R.D. (1993), Educational Stratification on Observed and Unobserved Components of Family Background, In: Shavit, Y. \& H.-P. Blossfeld (eds), Persistent Inequality: Changing Educational Attainment in Thirteen Countries, pp. 351-76, Boulder, Co : Westview Press.

Marks, G.N., Creswell, J. \& Ainley, J. (2006), Explaining Socioeconomic Inequalities in Student Achievement: The Role of Home and School Factors, Education Research and Evaluation, Vol. 12(2):105-128.

Metz, M. H. (1978), Classrooms \& Corridors: The Crisis of Authority in Desegregated Secondary Schools. Berkeley: University of California Press.

Muller, W. \& Karle, W. (1993), Social Selection in Educational Systems in Europe, European Sociological Review, Vol. 9: 1-23.

Oakes, J. (1985), Keeping Track: How Schools Structure Inequality. Yale University Press.

Oakes, J., Gamoran, A. \& Page, R. (1992), Curriculum Differentiation, Opportunities, Outcomes and Meanings, In: Y. Shavit \& W. Muller (eds.), From School to Work: A Comparative Study of Educational Qualifications and Occupational Destinations, Oxford: Oxford University Press.

OECD (2005), School Factors Related to Quality and Equity: Results from PISA 2000, Paris: OECD.

OECD (2006), Where Immigrant Students Succeed. Pisa 2003, Paris: OECD.

OECD (2007), PISA 2006. Sciences Competencies for Tomorrow's World, Paris: OECD.

Peaker, G.F. (1971), The Plowden Children Four Years Later. London: National Foundation for Education Research in England and Wales.

Pfeffer, P.T. (2008), Persistent Inequality in Educational Attainment and its Institutional Context, European Sociological Review, Vol. 25(5):543-565.

Rindermann, H. \& Ceci, S.J. (2009), Educational Policy and Country Outcomes in International Cognitive Competence, Perspectives on Psychological Science, 4, 551-568

Rosenbaum, J.E. (1976), Making Inequality: The Hidden Curriculum of High School Tracking. New York: Wiley.

Scheerens, J. \& Bosker, R.J. (1997), The Foundations of Educational Effectiveness, Pergamon, Oxford.

Shavit, Y. \& Blossfeld, H.P. (1993), Persistent Inequality: Changing Educational Attainment in Thirteen Countries. Westview Press.

Shavit, Y., Arum, R. \& Gamoran, A. (Eds) (2007), Stratification in Higher Education: A Comparative Study. Stanford: Stanford University Press.

Snijders, T.A.B. \& Bosker, R.J. (1999), Multilevel Analysis: An Introduction to Basic and Advanced Multilevel Modelling. London: Sage Publications.

McKay.

Spring, J.H. (1976), The Sorting Machine: National Educational Policy since 1945,

Stolle, D., Soraka, S. \& Johnston, R. (2008), When Does Diversity Erode Trust?

Neighboorhood Diversity, Interpersonal Trust and the Mediating Effect of Social Interactions, Political Studies, 56, 57-75.

Tuner, R.H. (1960), Sponsored and Contest Mobility and the School System, American Sociological Review, Vol. 25(6): 855-867.

Treiman, D. J. \& Yip, K.-B. (1989), Educational and Occupational Attainment in 21

Countries, In: M. L. Kohn (Ed.), Cross-National Research in Sociology, Newbury

Park/London/New Delhi: Sage

Tubergen, F. van (2005), The Integration of Immigrants in Cross-National Perspective.

Origin, Destination, and Community Effects. Ph.D. Universiteit Utrecht.

Voas, D., Crockett, A. \& Olson, D. V. A. (2002), Religious Pluralism and Participation:

Why Previous Research is Wrong, American Sociological Review, 67, 212-230. 
Willms, J.D. (1986), Social Class Segregation and Its Relationship to Pupil's Examination Results in Scotland, American Sociological Review, Vol. 51:224-241.

Willms, J.D. (1992), Monitoring School Performance: A Guide for Educators. Washington, DC: The Falmer Press. 
Table 1: The effects of individual characteristics, track characteristics, school characteristics, educational systems characteristics on reading score of native students ( $\mathrm{N}$ countries=15; $\mathrm{N}$ schools $=2861 ; \mathrm{N}$ tracks $=3311 ; \mathrm{N}$ students $=72329)$

\begin{tabular}{|c|c|c|c|c|c|c|c|}
\hline & M0 & M1 & M2 & M3 & M4 & M5 & M6 \\
\hline Constant & $\begin{array}{l}498.8 \\
(5.3)\end{array}$ & $\begin{array}{l}543.5 \\
(60.0) \\
\end{array}$ & $\begin{array}{l}453.8 \\
(64.3) \\
\end{array}$ & $\begin{array}{l}501.8 \\
(70.7) \\
\end{array}$ & $\begin{array}{l}478.5 \\
(62.4) \\
\end{array}$ & $\begin{array}{l}482.6 \\
(59.9) \\
\end{array}$ & $\begin{array}{l}483.4 \\
(59.8) \\
\end{array}$ \\
\hline \multicolumn{8}{|l|}{ Individual characteristics } \\
\hline Parental ESCS & & $\begin{array}{l}28.2^{* *} \\
(0.5)\end{array}$ & $\begin{array}{l}27.3^{* *} \\
(0.5)\end{array}$ & $\begin{array}{l}28.6^{* *} \\
(0.5)\end{array}$ & $\begin{array}{l}27.2^{* *} \\
(0.5)\end{array}$ & $\begin{array}{l}27.2^{* *} \\
(0.5)\end{array}$ & $\begin{array}{l}27.4 * * \\
(0.6)\end{array}$ \\
\hline Female & & $\begin{array}{l}30.9 * * \\
(0.5)\end{array}$ & $\begin{array}{l}30.8^{* *} \\
(0.5)\end{array}$ & $\begin{array}{l}30.6^{* *} \\
(0.5)\end{array}$ & $\begin{array}{l}30.6 * * \\
(0.5)\end{array}$ & $\begin{array}{l}30.6^{* *} \\
(0.5)\end{array}$ & $\begin{array}{l}30.6^{* *} \\
(0.5)\end{array}$ \\
\hline $\begin{array}{l}\text { Grade (destination country } \\
\text { centered) }\end{array}$ & & $\begin{array}{l}42.9 * * \\
(0.7)\end{array}$ & $\begin{array}{l}40.4^{* *} \\
(0.7)\end{array}$ & $\begin{array}{l}41.8^{* *} \\
(0.7)\end{array}$ & $\begin{array}{l}41.2^{* *} \\
(0.7)\end{array}$ & $\begin{array}{l}41.1^{* *} \\
(0.7)\end{array}$ & $\begin{array}{l}\text { 41.1** } \\
(0.7)\end{array}$ \\
\hline \multicolumn{8}{|l|}{$\begin{array}{l}\text { School-composition } \\
\text { characteristics at track-within- } \\
\text { school }\end{array}$} \\
\hline Average ESCS & & & $\begin{array}{l}50.2^{* *} \\
(3.1)\end{array}$ & & $\begin{array}{l}49.1^{* *} \\
(2.9)\end{array}$ & $\begin{array}{l}45.9^{* *} \\
(3.1)\end{array}$ & $\begin{array}{l}46.1^{* *} \\
(3.1)\end{array}$ \\
\hline $\begin{array}{l}\text { \% students from Eastern Europe } \\
\text { (ref=\% native students) }\end{array}$ & & & $-0.1(0.2)$ & & $-0.1(0.2)$ & $-0.1(0.2)$ & $-0.1(0.2)$ \\
\hline $\begin{array}{l}\text { \% students from non-Islam Asia } \\
\text { (ref=\% native students) }\end{array}$ & & & $\begin{array}{l}0.8^{* *} \\
(0.3) \\
\end{array}$ & & $\begin{array}{l}0.7^{* *} \\
(0.2) \\
\end{array}$ & $\begin{array}{l}0.5^{* *} \\
(0.2) \\
\end{array}$ & $\begin{array}{l}0.5^{* *} \\
(0.2) \\
\end{array}$ \\
\hline $\begin{array}{l}\text { \% students from Islamic countries } \\
\text { (ref=\% native students) }\end{array}$ & & & $0.2(0.2)$ & & $0.0(0.2)$ & $0.1(0.2)$ & $0.1(0.2)$ \\
\hline $\begin{array}{l}\text { \% students from western OECD } \\
\text { countries (ref=\% native students) }\end{array}$ & & & $\begin{array}{l}-0.5^{* *} \\
(0.2)\end{array}$ & & $-0.3(0.2)$ & $-0.3(0.2)$ & $-0.3(0.2)$ \\
\hline $\begin{array}{l}\text { \% students from Sub-Saharan } \\
\text { Africa (ref=\% native students) }\end{array}$ & & & $-0.6(0.4)$ & & $-0.5(0.4)$ & $-0.5(0.4)$ & $-0.5(0.4)$ \\
\hline ESCS diversity & & & $\begin{array}{l}19.5^{* *} \\
(7.9)\end{array}$ & & $-2.1(7.2)$ & $-3.5(7.2)$ & $-5.9(7.3)$ \\
\hline Ethnic diversity & & & $\begin{array}{l}-17.7 \\
(11.5)\end{array}$ & & $\begin{array}{l}-17.4 \\
(10.8)\end{array}$ & $\begin{array}{l}-16.0 \\
(10.9)\end{array}$ & $\begin{array}{l}-16.2 \\
(10.9)\end{array}$ \\
\hline \multicolumn{8}{|l|}{$\begin{array}{l}\text { Curriculum at track-within- } \\
\text { school }\end{array}$} \\
\hline Vocational (ref=general) & & & & $\begin{array}{l}-72.3^{* *} \\
(2.2)\end{array}$ & $\begin{array}{l}-52.6^{* *} \\
(2.4) \\
\end{array}$ & $\begin{array}{l}-52.4^{* *} \\
(2.4) \\
\end{array}$ & $\begin{array}{l}-52.4^{* *} \\
(2.4) \\
\end{array}$ \\
\hline Higher secondary (ref=lower) & & & & $-0.6(2.9)$ & $-4.2(2.9)$ & $-4.1(2.9)$ & $-4.2(2.9)$ \\
\hline $\begin{array}{l}\text { Selective admittance (ref= Some } \\
\text { selective admittance) }\end{array}$ & & & & $\begin{array}{l}21.5^{* *} \\
(2.7) \\
\end{array}$ & $\begin{array}{l}17.5^{* *} \\
(2.3)\end{array}$ & $\begin{array}{l}16.3^{* *} \\
(2.3)\end{array}$ & $\begin{array}{l}16.4^{* *} \\
(2.3)\end{array}$ \\
\hline $\begin{array}{l}\text { Non selective admittance (ref= } \\
\text { Some selective admittance) }\end{array}$ & & & & $\begin{array}{l}-5.8^{* *} \\
(1.9)\end{array}$ & $-0.8(1.7)$ & $-2.3(1.6)$ & $-2.3(1.6)$ \\
\hline \multicolumn{8}{|l|}{ School characteristics } \\
\hline Teacher shortage & & & & & & $\begin{array}{l}-4.8^{* *} \\
(0.8)\end{array}$ & $\begin{array}{l}-4.8^{* *} \\
(0.8)\end{array}$ \\
\hline Student/staff ratio & & & & & & $\begin{array}{l}0.5^{* *} \\
(0.2)\end{array}$ & $\begin{array}{l}0.5^{* *} \\
(0.2)\end{array}$ \\
\hline School in city (ref=towns) & & & & & & $-1.8(1.9)$ & $-1.8(1.9)$ \\
\hline School in rural (ref=towns) & & & & & & $\begin{array}{l}5.6^{* *} \\
(1.7)\end{array}$ & $\begin{array}{l}5.6^{* *} \\
(1.7)\end{array}$ \\
\hline School-size*100 & & & & & & $\begin{array}{l}1.3^{* *} \\
(0.2)\end{array}$ & $\begin{array}{l}1.4^{* *} \\
(0.2)\end{array}$ \\
\hline $\begin{array}{l}\text { Private dependent (ref=Public } \\
\text { school) }\end{array}$ & & & & & & $\begin{array}{l}-7.5^{* *} \\
(2.5) \\
\end{array}$ & $\begin{array}{l}-7.4^{* *} \\
(2.5) \\
\end{array}$ \\
\hline $\begin{array}{l}\text { Private independent (ref=Public } \\
\text { school) }\end{array}$ & & & & & & $\begin{array}{l}-9.5^{* *} \\
(4.0) \\
\end{array}$ & $\begin{array}{l}-9.1^{* *} \\
(4.0)\end{array}$ \\
\hline \multicolumn{8}{|l|}{$\begin{array}{l}\text { Educational system } \\
\text { characteristics }\end{array}$} \\
\hline $\begin{array}{l}\text { Strongly stratified (ref= } \\
\text { Comprehensive) }\end{array}$ & & $\begin{array}{l}-23.6 \\
(18.1)\end{array}$ & $\begin{array}{l}12.5 \\
(20.4)\end{array}$ & $\begin{array}{l}-23.2 \\
(22.4)\end{array}$ & $5.0(19.8)$ & $\begin{array}{l}-2.4 \\
(18.9)\end{array}$ & $\begin{array}{l}-1.9 \\
(18.9)\end{array}$ \\
\hline $\begin{array}{l}\text { Moderately stratified (ref= } \\
\text { Comprehensive) }\end{array}$ & & $\begin{array}{l}-22.3 \\
(13.1) \\
\end{array}$ & $\begin{array}{l}-13.5 \\
(14.8) \\
\end{array}$ & $\begin{array}{l}-45.5^{* *} \\
(16.6)\end{array}$ & $\begin{array}{l}-19.3 \\
(14.7) \\
\end{array}$ & $\begin{array}{l}-17.2 \\
(14.1) \\
\end{array}$ & $\begin{array}{l}-16.8 \\
(14.1) \\
\end{array}$ \\
\hline Age of selection & & $-3.5(3.5)$ & $0.8(4.0)$ & $-0.7(4.4)$ & $-0.3(3.9)$ & $-0.7(3.7)$ & $-0.7(3.7)$ \\
\hline $\begin{array}{l}\text { Interactions with educational } \\
\text { system }\end{array}$ & & & & & & & \\
\hline
\end{tabular}




\begin{tabular}{|c|c|c|c|c|c|c|c|}
\hline Parental ESCS* strongly stratified & & $\begin{array}{l}-15.1^{* *} \\
(0.8)\end{array}$ & $\begin{array}{l}-16.1^{* *} \\
(0.8)\end{array}$ & $\begin{array}{l}-15.8^{* *} \\
(0.8)\end{array}$ & $\begin{array}{l}-16.2^{* *} \\
(0.8)\end{array}$ & $\begin{array}{l}-16.2^{* *} \\
(0.8)\end{array}$ & $\begin{array}{l}-16.4^{* *} \\
(0.8)\end{array}$ \\
\hline $\begin{array}{l}\text { Parental ESCS* moderately } \\
\text { stratified }\end{array}$ & & $\begin{array}{l}-14.1 * * \\
(0.9)\end{array}$ & $\begin{array}{l}-15.8 * * \\
(0.8)\end{array}$ & $\begin{array}{l}-15.4^{* *} \\
(0.9)\end{array}$ & $\begin{array}{l}-15.8^{* *} \\
(0.9)\end{array}$ & $\begin{array}{l}-15.8^{* *} \\
(0.9)\end{array}$ & $\begin{array}{l}-15.9 * * \\
(0.9)\end{array}$ \\
\hline Average ESCS* strongly stratified & & & $4.2(3.9)$ & & $-5.8(3.7)$ & $-2.4(3.7)$ & $-2.6(3.7)$ \\
\hline $\begin{array}{l}\text { Average ESCS* moderately } \\
\text { stratified }\end{array}$ & & & $\begin{array}{l}28.2^{* *} \\
(4.4)\end{array}$ & & $2.8(4.3)$ & $6.5(4.3)$ & $6.4(4.3)$ \\
\hline $\begin{array}{l}\text { Higher secondary* strongly } \\
\text { stratified }\end{array}$ & & & & $\begin{array}{l}34.2^{* *} \\
(3.9)\end{array}$ & $\begin{array}{l}13.6^{* *} \\
(4.0)\end{array}$ & $\begin{array}{l}12.1^{* *} \\
(3.9)\end{array}$ & $\begin{array}{l}11.9 * * \\
(3.9)\end{array}$ \\
\hline $\begin{array}{l}\text { Higher secondary* moderately } \\
\text { stratified }\end{array}$ & & & & $\begin{array}{l}59.3^{* *} \\
(8.4)\end{array}$ & $\begin{array}{l}26.2^{* *} \\
(8.2)\end{array}$ & $\begin{array}{l}25.4^{* *} \\
(8.1)\end{array}$ & $\begin{array}{l}25.1^{* *} \\
(8.1)\end{array}$ \\
\hline \multicolumn{8}{|l|}{ Reproduction } \\
\hline Parental ESCS* average ESCS & & & & & & & $\begin{array}{l}-1.1^{*} \\
(0.6) \\
\end{array}$ \\
\hline \multicolumn{8}{|l|}{ Variation } \\
\hline Individual-level & $\begin{array}{l}5090.6 \\
(27.4)\end{array}$ & $\begin{array}{l}4447.3 \\
(23.9)\end{array}$ & $\begin{array}{l}4446.4 \\
(23.9)\end{array}$ & $\begin{array}{l}4448.0 \\
(23.9)\end{array}$ & $\begin{array}{l}4448.2 \\
(23.9)\end{array}$ & $\begin{array}{l}4447.7 \\
(23.9)\end{array}$ & $\begin{array}{l}4447.3 \\
(23.9)\end{array}$ \\
\hline Track-within-school-level & $\begin{array}{l}2288.2 \\
(165.2)\end{array}$ & $\begin{array}{l}947.0 \\
(83.8)\end{array}$ & $\begin{array}{l}562.4 \\
(58.4)\end{array}$ & $\begin{array}{l}309.4 \\
(42.9)\end{array}$ & $\begin{array}{l}312.5 \\
(42.4)\end{array}$ & $\begin{array}{l}308.4 \\
(41.9)\end{array}$ & $\begin{array}{l}307.7 \\
(41.9)\end{array}$ \\
\hline School-level & $\begin{array}{l}1221.2 \\
(169.4)\end{array}$ & $\begin{array}{l}1229.9 \\
(96.3)\end{array}$ & $\begin{array}{l}733.1 \\
(65.4)\end{array}$ & $\begin{array}{l}1258.8 \\
(60.9)\end{array}$ & $\begin{array}{l}796.1 \\
(51.5)\end{array}$ & $\begin{array}{l}756.6 \\
(50.3)\end{array}$ & $\begin{array}{l}759.0 \\
(50.4)\end{array}$ \\
\hline Country-level & $\begin{array}{l}391.8 \\
(154.8)\end{array}$ & $\begin{array}{l}258.2 \\
(102.3)\end{array}$ & $\begin{array}{l}336.8 \\
(128.9)\end{array}$ & $\begin{array}{l}401.2 \\
(153.4)\end{array}$ & $\begin{array}{l}309.3 \\
(118.5)\end{array}$ & $\begin{array}{l}280.4 \\
(107.3)\end{array}$ & $\begin{array}{l}279.6 \\
(107.1)\end{array}$ \\
\hline Log likelihood & 831363 & 820492 & 819109 & 819436 & 818579 & 818470 & 818466 \\
\hline
\end{tabular}

Source: PISA 2006; own computation 
Table 2: The effects of individual characteristics, track characteristics, school characteristics, educational systems characteristics on reading score of immigrant students ( $\mathrm{N}$ origin=35; $\mathrm{N}$ destination=15; $\mathrm{N}$ tracks=1960; $\mathrm{N}$ students=8521)

\begin{tabular}{|c|c|c|c|c|c|c|c|}
\hline & M0 & M1 & M2 & M3 & M4 & M5 & M6 \\
\hline Constant & $\begin{array}{l}470.6 \\
(8.2)\end{array}$ & $\begin{array}{l}502.0 \\
(46.2)\end{array}$ & $\begin{array}{l}446.4 \\
(43.3)\end{array}$ & $\begin{array}{l}488.3 \\
(45.2)\end{array}$ & $\begin{array}{l}465.2 \\
(43.6)\end{array}$ & $\begin{array}{l}457.5 \\
(44.2)\end{array}$ & $\begin{array}{l}457.7 \\
(44.2)\end{array}$ \\
\hline \multicolumn{8}{|l|}{ Individual characteristics } \\
\hline Parental ESCS & & $\begin{array}{l}32.9 * * \\
(2.0)\end{array}$ & $\begin{array}{l}25.0^{* *} \\
(2.1)\end{array}$ & $\begin{array}{l}33.4^{* *} \\
(2.0)\end{array}$ & $\begin{array}{l}25.0^{* *} \\
(2.1)\end{array}$ & $\begin{array}{l}24.9^{* *} \\
(2.1)\end{array}$ & $\begin{array}{l}25.0^{* *} \\
(2.1)\end{array}$ \\
\hline $\begin{array}{l}\text { Eastern Europe origin (ref= } \\
\text { Western OECD countries) }\end{array}$ & & $-7.0(7.4)$ & $-10.1(7.1)$ & $-5.9(6.9)$ & $-6.8(6.8)$ & $-8.2(6.8)$ & $-8.2(6.8)$ \\
\hline $\begin{array}{l}\text { Non-Islamic Asia origin (ref= } \\
\text { Western OECD countries) }\end{array}$ & & $\begin{array}{l}35.3^{* *} \\
(11.2)\end{array}$ & $\begin{array}{l}17.2 \\
(10.5)\end{array}$ & $\begin{array}{l}32.2 * * \\
(10.5)\end{array}$ & $\begin{array}{l}18.8^{*} \\
(10.2)\end{array}$ & $\begin{array}{l}18.7^{*} \\
(10.2)\end{array}$ & $\begin{array}{l}18.6^{*} \\
(10.2)\end{array}$ \\
\hline $\begin{array}{l}\text { Islamic countries origin (ref }= \\
\text { Western OECD countries) }\end{array}$ & & $\begin{array}{l}-38.2^{* *} \\
(9.3)\end{array}$ & $\begin{array}{l}-35.7^{* *} \\
(8.8)\end{array}$ & $\begin{array}{l}-38.9 * * \\
(8.7)\end{array}$ & $\begin{array}{l}-35.1^{* *} \\
(8.4)\end{array}$ & $\begin{array}{l}-35.3^{* *} \\
(8.4)\end{array}$ & $\begin{array}{l}-35.3^{* *} \\
(8.4)\end{array}$ \\
\hline $\begin{array}{l}\text { Sub-Saharan Africa origin (ref= } \\
\text { Western OECD countries) }\end{array}$ & & $\begin{array}{l}-22.7 \\
(16.0)\end{array}$ & $\begin{array}{l}-13.9 \\
(14.9)\end{array}$ & $\begin{array}{l}-25.6^{*} \\
(14.9)\end{array}$ & $\begin{array}{l}-15.8 \\
(14.3)\end{array}$ & $\begin{array}{l}-15.0 \\
(14.2)\end{array}$ & $\begin{array}{l}-15.0 \\
(14.2)\end{array}$ \\
\hline Female & & $\begin{array}{l}30.6^{* *} \\
(1.7)\end{array}$ & $\begin{array}{l}29.9^{* *} \\
(1.6)\end{array}$ & $\begin{array}{l}28.5^{* *} \\
(1.7)\end{array}$ & $\begin{array}{l}28.5^{* *} \\
(1.6)\end{array}$ & $\begin{array}{l}28.6^{* *} \\
(1.6)\end{array}$ & $\begin{array}{l}28.6^{* *} \\
(1.6)\end{array}$ \\
\hline $\begin{array}{l}\text { Home language same as in } \\
\text { destination country }\end{array}$ & & $\begin{array}{l}26.1^{* *} \\
(2.3)\end{array}$ & $\begin{array}{l}24.3^{* *} \\
(2.2)\end{array}$ & $\begin{array}{l}25.5^{* * *} \\
(2.2)\end{array}$ & $\begin{array}{l}24.2^{* *} \\
(2.2)\end{array}$ & $\begin{array}{l}24.2^{* *} \\
(2.2)\end{array}$ & $\begin{array}{l}24.2^{* *} \\
(2.2)\end{array}$ \\
\hline $\begin{array}{l}\text { One parent migrant, other parent } \\
\text { native }\end{array}$ & & $4.8(4.0)$ & $6.1(3.8)$ & $4.8(3.9)$ & $5.4(3.8)$ & $5.8(3.8)$ & $5.8(3.8)$ \\
\hline Second generation migrant & & $\begin{array}{l}9.2^{* *} \\
(1.9)\end{array}$ & $\begin{array}{l}9.7^{* *} \\
(1.9)\end{array}$ & $\begin{array}{l}8.5^{* *} \\
(1.9)\end{array}$ & $\begin{array}{l}9.3^{* *} \\
(1.8)\end{array}$ & $\begin{array}{l}9.4^{* *} \\
(1.8)\end{array}$ & $\begin{array}{l}9.3^{* *} \\
(1.8)\end{array}$ \\
\hline $\begin{array}{l}\text { Grade (destination country } \\
\text { centered) }\end{array}$ & & $\begin{array}{l}40.5^{* *} \\
(1.6)\end{array}$ & $\begin{array}{l}32.3 * * \\
(1.6)\end{array}$ & $\begin{array}{l}35.1^{* *} \\
(1.9)\end{array}$ & $\begin{array}{l}32.3^{* *} \\
(1.8)\end{array}$ & $\begin{array}{l}31.8^{* *} \\
(1.8)\end{array}$ & $\begin{array}{l}31.8^{* *} \\
(1.8)\end{array}$ \\
\hline \multicolumn{8}{|l|}{$\begin{array}{l}\text { School-composition } \\
\text { characteristics at track-within- } \\
\text { school }\end{array}$} \\
\hline Average ESCS & & & $\begin{array}{l}49.8^{* *} \\
(4.8)\end{array}$ & & $\begin{array}{l}49.0^{* *} \\
(4.7)\end{array}$ & $\begin{array}{l}46.8^{* *} \\
(5.1)\end{array}$ & $\begin{array}{l}46.9^{* *} \\
(5.1)\end{array}$ \\
\hline $\begin{array}{l}\text { \% students from Eastern Europe } \\
\text { (ref=\% native students) }\end{array}$ & & & $0.3(0.2)$ & & $0.3(0.2)$ & $\begin{array}{l}0.4^{* *} \\
(0.2) \\
\end{array}$ & $\begin{array}{l}0.4^{* *} \\
(0.2)\end{array}$ \\
\hline $\begin{array}{l}\text { \% students from non-Islamic Asia } \\
\text { (ref=\% native students) }\end{array}$ & & & $\begin{array}{l}1.4^{* *} \\
(0.2)\end{array}$ & & $\begin{array}{l}1.3^{* *} \\
(0.2)\end{array}$ & $\begin{array}{l}1.2^{* *} \\
(0.2)\end{array}$ & $\begin{array}{l}1.2^{* *} \\
(0.2)\end{array}$ \\
\hline $\begin{array}{l}\text { \% students from Islamic countries } \\
\text { (ref=\% native students) }\end{array}$ & & & $0.2(0.1)$ & & $0.0(0.1)$ & $0.1(0.1)$ & $0.1(0.1)$ \\
\hline $\begin{array}{l}\text { \% students from Western OECD } \\
\text { countries (ref=\% native students) }\end{array}$ & & & $-0.1(0.1)$ & & $0.0(0.1)$ & $0.0(0.1)$ & $0.0(0.1)$ \\
\hline $\begin{array}{l}\text { \% students from Sub-Saharan } \\
\text { Africa (ref=\% native students) }\end{array}$ & & & $-0.2(0.4)$ & & $-0.1(0.4)$ & $-0.2(0.4)$ & $-0.2(0.4)$ \\
\hline ESCS diversity & & & $\begin{array}{l}45.5^{* *} \\
(14.1)\end{array}$ & & $\begin{array}{l}22.9 \\
(13.9) \\
\end{array}$ & $\begin{array}{l}20.4 \\
(13.9)\end{array}$ & $\begin{array}{l}20.0 \\
(14.0) \\
\end{array}$ \\
\hline Ethnic diversity & & & $\begin{array}{l}-36.1^{* *} \\
(11.4)\end{array}$ & & $\begin{array}{l}-36.9 * * \\
(11.0)\end{array}$ & $\begin{array}{l}-40.1^{* *} \\
(11.2)\end{array}$ & $\begin{array}{l}-40.3^{* *} \\
(11.2)\end{array}$ \\
\hline \multicolumn{8}{|l|}{$\begin{array}{l}\text { Curriculum at track-within- } \\
\text { school }\end{array}$} \\
\hline Vocational (ref=general) & & & & $\begin{array}{l}-85.8^{* *} \\
(4.5) \\
\end{array}$ & $\begin{array}{l}-54.5^{* *} \\
(4.6) \\
\end{array}$ & $\begin{array}{l}-54.1^{* *} \\
(4.6) \\
\end{array}$ & $\begin{array}{l}-54.1^{* *} \\
(4.6) \\
\end{array}$ \\
\hline Higher secondary (ref=lower) & & & & $-0.5(5.2)$ & $0.5(4.9)$ & $-0.7(4.9)$ & $-0.8(4.9)$ \\
\hline $\begin{array}{l}\text { Selective admittance (ref= Some } \\
\text { selective admittance) }\end{array}$ & & & & $\begin{array}{l}21.4^{* *} \\
(3.0)\end{array}$ & $\begin{array}{l}17.7^{* *} \\
(2.7)\end{array}$ & $\begin{array}{l}18.0^{* *} \\
(2.8)\end{array}$ & $\begin{array}{l}18.0^{* *} \\
(2.8)\end{array}$ \\
\hline $\begin{array}{l}\text { Non selective admittance (ref= } \\
\text { Some selective admittance) }\end{array}$ & & & & $0.2(2.6)$ & $2.2(2.4)$ & $1.0(2.4)$ & $1.0(2.4)$ \\
\hline \multicolumn{8}{|l|}{ School characteristics } \\
\hline Teacher shortage & & & & & & $-1.6(1.1)$ & $-1.6(1.1)$ \\
\hline Student/staff ratio & & & & & & $\begin{array}{l}0.8^{* *} \\
(0.3)\end{array}$ & $\begin{array}{l}0.8^{* *} \\
(0.3)\end{array}$ \\
\hline School in city (ref=towns) & & & & & & $2.7(2.7)$ & $2.7(2.7)$ \\
\hline School in rural (ref=towns) & & & & & & $2.7(2.7)$ & $2.7(2.7)$ \\
\hline School-size*100 & & & & & & $0.7^{* *}$ & $0.7^{* *}$ \\
\hline
\end{tabular}




\begin{tabular}{|c|c|c|c|c|c|c|c|}
\hline & & & & & & $(0.2)$ & $(0.2)$ \\
\hline $\begin{array}{l}\text { Private dependent (ref=Public } \\
\text { school) }\end{array}$ & & & & & & $-5.0(3.7)$ & $-4.9(3.7)$ \\
\hline $\begin{array}{l}\text { Private independent (ref=Public } \\
\text { school) }\end{array}$ & & & & & & $-6.6(5.4)$ & $-6.4(5.4)$ \\
\hline \multicolumn{8}{|l|}{$\begin{array}{l}\text { Educational system } \\
\text { characteristics }\end{array}$} \\
\hline $\begin{array}{l}\text { Strongly stratified (ref= } \\
\text { Comprehensive) }\end{array}$ & & $\begin{array}{l}-28.8^{*} \\
(15.4)\end{array}$ & $-9.6(14.4)$ & $\begin{array}{l}-41.1^{* *} \\
(15.0)\end{array}$ & $\begin{array}{l}-15.4 \\
(14.4)\end{array}$ & $\begin{array}{l}-16.7 \\
(14.5)\end{array}$ & $\begin{array}{l}-16.7 \\
(14.5)\end{array}$ \\
\hline $\begin{array}{l}\text { Moderately stratified (ref= } \\
\text { Comprehensive) }\end{array}$ & & $\begin{array}{l}-25.3^{*} \\
(13.6)\end{array}$ & $\begin{array}{l}-10.3 \\
(12.6)\end{array}$ & $\begin{array}{l}-41.1^{* *} \\
(13.6)\end{array}$ & $\begin{array}{l}-20.1 \\
(13.0)\end{array}$ & $\begin{array}{l}-16.7 \\
(13.1)\end{array}$ & $\begin{array}{l}-16.7 \\
(13.1)\end{array}$ \\
\hline Age of selection & & $-3.1(2.8)$ & $-1.8(2.6)$ & $-2.1(2.8)$ & $-2.1(2.6)$ & $-2.3(2.6)$ & $-2.3(2.6)$ \\
\hline \multicolumn{8}{|l|}{$\begin{array}{l}\text { Interactions with educational } \\
\text { systems }\end{array}$} \\
\hline Parental ESCS* strongly stratified & & $\begin{array}{l}-16.1^{* *} \\
(2.4)\end{array}$ & $\begin{array}{l}-16.5^{* *} \\
(2.5)\end{array}$ & $\begin{array}{l}-18.5^{* *} \\
(2.3)\end{array}$ & $\begin{array}{l}-16.5^{* *} \\
(2.4)\end{array}$ & $\begin{array}{l}-16.4^{* *} \\
(2.4)\end{array}$ & $\begin{array}{l}-16.5^{* *} \\
(2.5)\end{array}$ \\
\hline $\begin{array}{l}\text { Parental ESCS* moderately } \\
\text { stratified }\end{array}$ & & $\begin{array}{l}-14.1^{* *} \\
(3.2)\end{array}$ & $\begin{array}{l}-15.8^{* *} \\
(3.3)\end{array}$ & $\begin{array}{l}-21.5^{* *} \\
(3.2)\end{array}$ & $\begin{array}{l}-16.3^{* *} \\
(3.3)\end{array}$ & $\begin{array}{l}-16.3^{* *} \\
(3.3)\end{array}$ & $\begin{array}{l}-16.5^{* *} \\
(3.3)\end{array}$ \\
\hline Average ESCS* strongly stratified & & & $\begin{array}{l}29.8^{* *} \\
(5.9)\end{array}$ & & $\begin{array}{l}18.1^{* *} \\
(5.9)\end{array}$ & $\begin{array}{l}19.6^{* *} \\
(6.1)\end{array}$ & $\begin{array}{l}19.5^{* *} \\
(6.2)\end{array}$ \\
\hline $\begin{array}{l}\text { Average ESCS* moderately } \\
\text { stratified }\end{array}$ & & & $\begin{array}{l}18.4^{* *} \\
(7.7)\end{array}$ & & $\begin{array}{l}-11.8 \\
(8.0)\end{array}$ & $\begin{array}{l}-10.8 \\
(8.3)\end{array}$ & $\begin{array}{l}-11.0 \\
(8.3)\end{array}$ \\
\hline $\begin{array}{l}\text { Higher secondary* strongly } \\
\text { stratified }\end{array}$ & & & & $\begin{array}{l}53.1^{* *} \\
(6.7)\end{array}$ & $\begin{array}{l}16.1^{* *} \\
(6.5)\end{array}$ & $\begin{array}{l}16.1^{* *} \\
(6.5)\end{array}$ & $\begin{array}{l}16.3^{* *} \\
(6.5)\end{array}$ \\
\hline $\begin{array}{l}\text { Higher secondary* moderately } \\
\text { stratified }\end{array}$ & & & & $\begin{array}{l}49.1^{* *} \\
(10.1)\end{array}$ & $\begin{array}{l}31.3^{* *} \\
(9.8)\end{array}$ & $\begin{array}{l}32.8 * * \\
(9.8)\end{array}$ & $\begin{array}{l}32.7 * * \\
(9.8)\end{array}$ \\
\hline \multicolumn{8}{|l|}{ Reproduction } \\
\hline Parental ESCS* average ESCS & & & & & & & $-0.5(1.8)$ \\
\hline \multicolumn{8}{|l|}{ Variation } \\
\hline Individual-level & $\begin{array}{l}5034.3 \\
(104.9)\end{array}$ & $\begin{array}{l}4599.5 \\
(94.1)\end{array}$ & $\begin{array}{l}4506.7 \\
(89.8)\end{array}$ & $\begin{array}{l}4547.0 \\
(91.8)\end{array}$ & $\begin{array}{l}4520.7 \\
(89.1)\end{array}$ & $\begin{array}{l}4516.2 \\
(89.0)\end{array}$ & $\begin{array}{l}4516.2 \\
(89.0)\end{array}$ \\
\hline Track-within-school-level & $\begin{array}{l}3338.4 \\
(155.9)\end{array}$ & $\begin{array}{l}1941.0 \\
(114.2)\end{array}$ & $\begin{array}{l}1129.0 \\
(89.6)\end{array}$ & $\begin{array}{l}1481.4 \\
(100.7)\end{array}$ & $\begin{array}{l}931.5 \\
(83.4)\end{array}$ & $\begin{array}{l}917.3 \\
(82.8)\end{array}$ & $\begin{array}{l}917.1 \\
(82.8)\end{array}$ \\
\hline Origin-country-level & $\begin{array}{l}1875.4 \\
(256.9)\end{array}$ & $\begin{array}{l}000.0 \\
(00.0)\end{array}$ & $\begin{array}{l}384.9 \\
(1719.4)\end{array}$ & $\begin{array}{l}000.0 \\
(00.0)\end{array}$ & $\begin{array}{l}000.0 \\
(00.0)\end{array}$ & $\begin{array}{r}000.0 \\
(00.0)\end{array}$ & $\begin{array}{r}000.0 \\
(00.0)\end{array}$ \\
\hline Destination-country-level & $\begin{array}{l}000.0 \\
(00.0)\end{array}$ & $\begin{array}{l}581.4 \\
(120.7)\end{array}$ & $\begin{array}{l}112.6 \\
(1718.0)\end{array}$ & $\begin{array}{l}504.2 \\
(104.5)\end{array}$ & $\begin{array}{l}455.7 \\
(93.6)\end{array}$ & $\begin{array}{l}444.8 \\
(91.8)\end{array}$ & $\begin{array}{l}444.6 \\
(91.7)\end{array}$ \\
\hline Log likelihood & 100118 & 98448 & 97536 & 97951 & 97339 & 97315 & 97314 \\
\hline
\end{tabular}

Source: PISA 2006; own computations. 
Table 3: Summary of the different effects of parental ESCS, average ESCS schoolcomposition, and track-level in different educational systems.

\begin{tabular}{|l|r|r|r|r|r|r|}
\hline & \multicolumn{3}{|c|}{$\begin{array}{c}\text { First generation immigrant students from } \\
\text { Western OECD countries }\end{array}$} & \multicolumn{3}{c|}{ Native students } \\
\hline & Comprehensive & \multicolumn{1}{|c|}{ Moderately } & \multicolumn{1}{l|}{ Strongly } & Comprehensive & Moderately & Strongly \\
\hline Average & 457.7 & 441.0 & 441.0 & 483.4 & 466.6 & 481.5 \\
\hline $\begin{array}{l}\text { Parental } \\
\text { ESCS }\end{array}$ & 25.0 & 8.5 & 8.5 & 27.4 & 11.5 & 11.0 \\
\hline $\begin{array}{l}\text { School } \\
\text { ESCS }\end{array}$ & 46.9 & 35.9 & 63.2 & 46.1 & 52.5 & 43.5 \\
\hline $\begin{array}{l}\text { Track- } \\
\text { level }\end{array}$ & -0.8 & 31.9 & 15.5 & -4.2 & 20.9 & 7.7 \\
\hline
\end{tabular}

Source: PISA 2006; own computation. The average scores of the immigrant students from Eastern-Europe, non-Islam Asia, Islamic countries and Sub-Saharan African countries can be found by changing the scores for the Western OECD immigrants with -8.2, +18.6, -35.3 and -15.0 respectively. The average scores of second-generation immigrant students should be changed with +9.3 , of those who use the same language as the destination country with +24.2 and those with mixed parents with +5.8 . 
Table 4: Estimation of educational performance of first generation immigrants from Western OECD countries and native students with lowest and highest parental ESCS, in schools with lowest and highest ESCS composition and with different track-level in the three educational systems, based on models 6 of tables 1 and 2 .

$\begin{array}{lllllll}\text { School } & & \text { highest } & \text { lowest } & \text { highest } & \text { lowest } & \text { highest } \\ \text { ECSC } & \text { lowest parent } & \text { parent } & \text { parent } & \text { parent } & \text { parent } & \text { parent } \\ \text { composition } & \text { ECSC \& } & \text { ECSC \& } & \text { ECSC \& } & \text { ECSC \& } & \text { ECSC \& } & \text { ECSC \& } \\ & \text { vocational } & \text { vocational } & \text { general } & \text { general } & \text { general } & \text { general } \\ & \text { \& lower } & \text { \& lower } & \text { \& lower } & \text { \& lower } & \text { \& higher } & \text { \& higher }\end{array}$
First generation immigrants students from Western OECD-countries

\begin{tabular}{|c|c|c|c|c|c|c|c|}
\hline \multirow[t]{2}{*}{ Comprehensive } & Lowest & 199 & 385 & 246 & 439 & 254 & 447 \\
\hline & Highest & 374 & 553 & 428 & 607 & 427 & 606 \\
\hline \multirow[t]{2}{*}{ Moderately } & Lowest & 259 & 323 & 307 & 378 & 346 & 416 \\
\hline & Highest & 412 & 469 & 466 & 523 & 498 & 555 \\
\hline \multirow[t]{2}{*}{ Strongly } & Lowest & 214 & 278 & 262 & 332 & 277 & 348 \\
\hline & Highest & 462 & 519 & 516 & 573 & 532 & 588 \\
\hline \multicolumn{8}{|c|}{ Native students } \\
\hline \multirow[t]{2}{*}{ Comprehensive } & Lowest & 218 & 428 & 271 & 481 & 267 & 477 \\
\hline & Highest & 416 & 593 & 469 & 646 & 464 & 641 \\
\hline \multirow[t]{2}{*}{ Moderately } & Lowest & 283 & 370 & 335 & 423 & 331 & 418 \\
\hline & Highest & 505 & 560 & 558 & 612 & 553 & 608 \\
\hline \multirow[t]{2}{*}{ Strongly } & Lowest & 306 & 390 & 359 & 442 & 359 & 422 \\
\hline & Highest & 494 & 545 & 546 & 597 & 546 & 597 \\
\hline
\end{tabular}


Appendix A: descriptive statistics for native and immigrant students separately

\begin{tabular}{|c|c|c|c|c|c|c|c|c|}
\hline & \multicolumn{4}{|c|}{ Native students } & \multicolumn{4}{|c|}{ Immigrant students } \\
\hline & Min. & Max. & Mean & \begin{tabular}{|l|} 
Std. \\
Deviation
\end{tabular} & Min. & Max. & Mean & \begin{tabular}{|l|} 
Std. \\
Deviation
\end{tabular} \\
\hline Science & 107,74 & 825,65 & 517,4749 & 91,42546 & 130,30 & 841,04 & 468,6504 & 103,36225 \\
\hline Math & 81,55 & 804,63 & 516,2721 & 87,44408 & 154,92 & 790,07 & 479,8127 & 94,65479 \\
\hline Reading & 81,02 & 800,16 & 505,7618 & 91,74740 & 67,34 & 775,21 & 462,9986 & 102,80869 \\
\hline Average ESCS school & $-2,19$ & 1,69 &, 1445 &, 50278 & $-2,07$ & 1,64 & 0345 &, 50160 \\
\hline Diversity ESCS &, 00 &, 80 &, 6511 &, 08432 &, 00 &, 79 &, 6635 &, 07145 \\
\hline Diversity Ethnic &, 00 &, 84 &, 1315 &, 16457 &, 03 &, 84 &, 4149 &, 19621 \\
\hline$\%$ Western OECD &, 00 & 91,80 & 3,6089 & 7,63365 &, 00 & 100,00 & 14,7488 & 18,62151 \\
\hline \% Eastern Europe &, 00 & 66,67 & 2,2934 & 5,70455 &, 00 & 66,67 & 7,9945 & 12,80759 \\
\hline \% Islamic countries &, 00 & 92,31 & 1,2043 & 4,25382 &, 00 & 92,31 & 5,9732 & 13,45775 \\
\hline$\%$ non-Islamic Asia &, 00 & 83,33 &, 7722 & 3,35355 &, 00 & 87,50 & 2,5286 & 8,11845 \\
\hline \% Sub-Saharan Africa &, 00 & 33,33 &, 2849 & 1,38090 &, 00 & 33,33 & 1,1262 & 3,09810 \\
\hline $\begin{array}{l}\text { Vocational orientation of } \\
\text { school }\end{array}$ &, 00 & 1,00 &, 0678 &, 25148 &, 00 & 1,00 & 0817 &, 27389 \\
\hline Level of track &, 00 & 1,00 &, 3900 & ,48756 &, 00 & 1,00 & ,3441 &, 47506 \\
\hline Level of track centered & $-1,00$ & 1,00 &,- 1227 & 88899 & $-1,00$ & 1,00 &,- 2881 &, 90094 \\
\hline School size & 9 & 4468 & 682,67 & 447,172 & 23 & 4468 & 845,77 & 629,165 \\
\hline Teacher-student ratio &, 889 & 36,588 & 11,79027 & 3,738107 &, 889 & 36,588 & 11,69007 & 3,942775 \\
\hline Teacher shortage & $-1,0568$ & 3,6194 &, 088128 &, 9539011 & $-1,0568$ & 3,6194 & 287914 & ,9777337 \\
\hline School in rural area &, 00 & 1,00 &, 3944 & 48872 &, 00 & 1,00 & 2949 &, 45603 \\
\hline School in city &, 00 & 1,00 &, 2594 & 43831 &, 00 & 1,00 & 3717 & ,48328 \\
\hline $\begin{array}{l}\text { School admittance not } \\
\text { selective }\end{array}$ &, 00 & 1,00 & ,4298 & 48725 &, 00 & 1,00 &, 2732 &, 44011 \\
\hline School admittance selective &, 00 & 1,00 & 1437 & 34489 &, 00 & 1,00 & 2259 & ,41509 \\
\hline Private independent school &, 00 & 1,00 &, 0443 & 20575 &, 00 & 1,00 &, 0501 &, 21819 \\
\hline Private dependent school &, 00 & 1,00 &, 2564 & 43663 &, 00 & 1,00 & 2402 &, 42725 \\
\hline Public school &, 00 & 1,00 &, 6993 & 45855 &, 00 & 1,00 & 7097 &, 45395 \\
\hline Female &, 00 & 1,00 & 4984 & 50000 &, 00 & 1,00 &, 5008 &, 50003 \\
\hline ECSC & $-4,3905$ & 3,3487 &, 175748 & 8911239 & $-4,4421$ & 2,9709 &,- 232409 & 1,0159425 \\
\hline Immigrant first generation & & & & &, 00 & 1,00 & 4605 &, 49847 \\
\hline Immigrant second generation & & & & &, 00 & 1,00 &, 5003 &, 50003 \\
\hline Mixed marriage & & & & &, 00 & 1,00 &, 0563 &, 23057 \\
\hline Eastern Europe & & & & &, 00 & 1,00 & 2746 &, 44635 \\
\hline Western OECD & & & & &, 00 & 1,00 & 4538 & ,49789 \\
\hline Islamic country & & & & &, 00 & 1,00 & 1620 &, 36843 \\
\hline Non-Islamic Asia & & & & &, 00 & 1,00 &, 0908 &, 28739 \\
\hline Sub-Saharan Africa & & & & &, 00 & 1,00 & 0354 &, 18490 \\
\hline Language of destination & & & & &, 00 & 1,00 & ,4995 &, 50003 \\
\hline $\begin{array}{l}\text { Grade (destination country } \\
\text { centered) }\end{array}$ & $-2,00$ & 3,00 &, 5924 & ,80276 & $-2,00$ & 3,00 &, 3732 &, 87115 \\
\hline Strongly stratified system &, 00 & 1,00 &, 3493 & ,47677 &, 00 & 1,00 &, 5645 &, 49585 \\
\hline Moderately stratified system &, 00 & 1,00 &, 2237 & 41672 &, 00 & 1,00 & 1402 &, 34726 \\
\hline Age of first selection & 10,00 & 16,00 & 14,0619 & 2,19505 & 10,00 & 16,00 & 13,2238 & 2,08364 \\
\hline Valid N & 72329 & & & & 8521 & & & \\
\hline
\end{tabular}

Source: PISA 2006; own computations. 
Appendix B: The number of schools and number of tracks-within-schools and the number of students in these tracks-within-schools (Number of students of track-within-school $>5$ )

\begin{tabular}{|c|c|c|c|c|c|c|}
\hline Country & Level & $\begin{array}{c}\mathrm{N} \\
\text { tracks- } \\
\text { within- } \\
\text { schools }\end{array}$ & $\begin{array}{l}\text { Minimum N } \\
\text { students per } \\
\text { track-within- } \\
\text { school }\end{array}$ & $\begin{array}{c}\text { Maximum N } \\
\text { students per } \\
\text { track-within- } \\
\text { school }\end{array}$ & $\begin{array}{c}\text { Average } \mathrm{N} \\
\text { students per } \\
\text { track- } \\
\text { within- } \\
\text { school } \\
\end{array}$ & $\begin{array}{c}\text { Level } \\
\text { centered per } \\
\text { country and } \\
\text { general/ } \\
\text { vocational } \\
\end{array}$ \\
\hline \multirow[t]{3}{*}{ Australia } & lower general & 345 & 6 & 56 & 31,87 & -1 \\
\hline & higher general & 133 & 6 & 33 & 16,37 & +1 \\
\hline & higher vocational & 10 & 6 & 19 & 9,10 & 0 \\
\hline \multirow[t]{3}{*}{ Austria } & lower general & 11 & 6 & 26 & 9,64 & -1 \\
\hline & higher general & 88 & 6 & 35 & 29,51 & +1 \\
\hline & higher vocational & 79 & 8 & 38 & 26,06 & 0 \\
\hline \multirow[t]{4}{*}{ Belgium } & lower general & 8 & 6 & 18 & 8,50 & -1 \\
\hline & lower vocational & 12 & 6 & 29 & 14,33 & -1 \\
\hline & higher general & 250 & 6 & 161 & 26,76 & +1 \\
\hline & higher vocational & 113 & 6 & 66 & 12,64 & +1 \\
\hline \multirow[t]{3}{*}{ Switzerland } & lower general & 458 & 6 & 175 & 23,61 & -1 \\
\hline & higher general & 37 & 6 & 34 & 16,57 & +1 \\
\hline & higher vocational & 17 & 6 & 33 & 15,94 & 0 \\
\hline \multirow[t]{4}{*}{ Germany } & lower vocational & 3 & 9 & 17 & 10,0 & -1 \\
\hline & lower general & 118 & 9 & 25 & 20,20 & 0 \\
\hline & higher vocational & 5 & 8 & 25 & 15,40 & 0 \\
\hline & higher general & 96 & 6 & 25 & 20,59 & +1 \\
\hline \multirow[t]{2}{*}{ Denmark } & lower general & 201 & 6 & 28 & 21,64 & -1 \\
\hline & higher general & 2 & 6 & 7 & 6,50 & +1 \\
\hline Finland & lower general & 154 & 7 & 35 & 30,24 & 0 \\
\hline Scotland & higher general & 98 & 9 & 34 & 23,84 & 0 \\
\hline \multirow[t]{3}{*}{ Greece } & lower general & 11 & 6 & 27 & 11,64 & -1 \\
\hline & higher general & 125 & 8 & 35 & 30,66 & +1 \\
\hline & higher vocational & 29 & 7 & 34 & 23,93 & 0 \\
\hline \multirow[t]{2}{*}{ Liechtenstein } & lower general & 11 & 6 & 77 & 27,18 & -1 \\
\hline & higher general & 2 & 11 & 26 & 18,50 & +1 \\
\hline \multirow[t]{3}{*}{ Luxembourg } & lower general & 28 & 11 & 205 & 96,71 & -1 \\
\hline & higher general & 27 & 6 & 125 & 49,33 & +1 \\
\hline & higher vocational & 14 & 6 & 32 & 16,64 & 0 \\
\hline \multirow[t]{2}{*}{ Latvia } & lower general & 171 & 7 & 35 & 26,25 & 0 \\
\hline & higher vocational & 7 & 6 & 21 & 9,86 & 0 \\
\hline \multirow[t]{2}{*}{ Norway } & lower general & 191 & 6 & 30 & 23,28 & -1 \\
\hline & higher general & 1 & 7 & 7 & 7,00 & +1 \\
\hline \multirow[t]{2}{*}{ New Zealand } & lower general & 3 & 6 & 12 & 9,00 & -1 \\
\hline & higher general & 168 & 10 & 50 & 24,43 & +1 \\
\hline \multirow[t]{4}{*}{ Portugal } & lower general & 123 & 6 & 37 & 16,41 & -1 \\
\hline & lower vocational & 6 & 6 & 17 & 9,83 & -1 \\
\hline & higher general & 111 & 6 & 37 & 18,14 & +1 \\
\hline & higher vocational & 47 & 6 & 34 & 9,57 & +1 \\
\hline \multirow[t]{2}{*}{ Total Natives } & Schools & 2861 & & & & \\
\hline & \begin{tabular}{|l} 
Tracks-within- \\
schools \\
\end{tabular} & 3311 & & & & \\
\hline \multirow[t]{2}{*}{ Immigrants } & \begin{tabular}{|l|} 
Schools \\
\end{tabular} & 1756 & & & & \\
\hline & $\begin{array}{l}\text { Tracks-within- } \\
\text { schools }\end{array}$ & 1960 & & & & \\
\hline
\end{tabular}

\footnotetext{
Source: PISA 2006; own computations.
} 
Appendix C. Average reading score of immigrant students per country of destination and country of origin $(\mathrm{N}=8521)$

\begin{tabular}{|c|c|c|c|c|c|c|c|c|c|c|c|c|c|c|c|c|}
\hline \multicolumn{17}{|c|}{ Destination countries } \\
\hline Origin countries & $\mathrm{AU}$ & AT & $\mathrm{BE}$ & $\mathrm{CH}$ & $\overline{\mathrm{DE}}$ & DK & EL & FI & LI & $\mathrm{LU}$ & LV & $\mathrm{NO}$ & $\mathrm{NZ}$ & $\mathrm{PT}$ & $\mathrm{SC}$ & Mean \\
\hline Australia & & & & & & & & & & & & & 551 & & & 551 \\
\hline Bangladesh & & & & & & & & & & & & & & & 453 & 453 \\
\hline Belarus & & & & & & & & & & & 486 & & & & & 486 \\
\hline Belgium & & & & & & & & & & 521 & & & & & & 521 \\
\hline Cap Verde & & & & & & & & & & 368 & & & & & & 368 \\
\hline China & 544 & 574 & & & & & & & & & & & 538 & 456 & 461 & 539 \\
\hline Congo & & & 437 & & & & & & & & & & & & & 437 \\
\hline Croatia & & 469 & & & 432 & & & & & & & & & & & 459 \\
\hline Czech republic & & 560 & & & & & & & & & & & & & & 560 \\
\hline Greece & & & & & 412 & & & & & & & & & & & 412 \\
\hline Hungary & & 567 & & & & & & & & & & & & & & 567 \\
\hline India & 539 & & & & & & & & & & & & & & 494 & 538 \\
\hline Italy & & & & 451 & 410 & & & & 447 & 432 & & & & & & 443 \\
\hline Korea & 499 & & & & & & & & & & & & 512 & & & 506 \\
\hline Liechtenstein & & & & 464 & & & & & & & & & & & & 464 \\
\hline Macedonia & & 401 & & & 413 & & & & & & & & & & & 403 \\
\hline Morocco & & & 442 & & & & & & & & & & & & & 442 \\
\hline Netherlands & & & 489 & & & & & & & & & & & & & 489 \\
\hline New Zealand & 498 & & & & & & & & & & & & & & & 498 \\
\hline Pakistan & & & & & & 408 & & & & & & & & & 446 & 423 \\
\hline Slovakia & & 515 & & & & & & & & & & & & & & 515 \\
\hline Slovenia & & 428 & & & 447 & & & & & & & & & & & 432 \\
\hline South Africa & 527 & & & & & & & & & & & & & & & 527 \\
\hline Spain & & & & 467 & & & & & 517 & & & & & & & 469 \\
\hline Sweden & & & & & & & & 497 & & & & 451 & & & & 462 \\
\hline Switzerland & & & & & & & & & 501 & & & & & & & 501 \\
\hline Turkey & & 386 & 411 & 433 & 400 & 398 & & & 359 & & & & & & & 408 \\
\hline Ukraine & & & & & & & & & & & 447 & & & & & 447 \\
\hline United Kingdom & 523 & & & & & & & & & & & & 554 & & & 532 \\
\hline United States & 559 & & & & & & & & & & & & & & & 559 \\
\hline Vietnam & 505 & & & & & & & & & & & & & & & 505 \\
\hline Mean immigrants & 523 & 445 & 451 & 444 & 430 & 412 & 433 & 532 & 482 & 440 & 465 & 429 & 520 & 465 & 456 & 463 \\
\hline
\end{tabular}


Appendix D: The effects of individual characteristics and educational systems characteristics (model 6 in tables 1 and 2) on reading scores of immigrant and native students in analyses with 4 or 2 levels.

\begin{tabular}{|c|c|c|c|c|c|c|}
\hline & \multicolumn{3}{|c|}{ Immigrant students } & \multicolumn{3}{|c|}{ Native students } \\
\hline & $\begin{array}{l}\text { Model 1; } 4 \\
\text { levels }\end{array}$ & $\begin{array}{l}\text { Model 1; } 2 \\
\text { levels }\end{array}$ & $\begin{array}{l}\text { Only ESCS } \\
\& \text { female }\end{array}$ & $\begin{array}{l}\text { Model 1; } 4 \\
\text { levels }\end{array}$ & $\begin{array}{l}\text { Model 1; } 2 \\
\text { levels }\end{array}$ & $\begin{array}{l}\text { Only ESCS } \\
\& \text { female }\end{array}$ \\
\hline Constant & $\begin{array}{l}502.0 \\
(46.2)\end{array}$ & $\begin{array}{l}478.9 \\
(75.8)\end{array}$ & $465.8(9.7)$ & $\begin{array}{l}543.5 \\
(60.0)\end{array}$ & $\begin{array}{l}559.1 \\
(58.4)\end{array}$ & $482.1(7.2)$ \\
\hline \multicolumn{7}{|l|}{ Individual characteristics } \\
\hline Parental ESCS & $\begin{array}{l}32.9 * * \\
(2.0)\end{array}$ & $\begin{array}{l}39.1^{* *} \\
(2.0)\end{array}$ & $40.7^{* *}(1.9)$ & $\begin{array}{l}28.2 * * \\
(0.5)\end{array}$ & $\begin{array}{l}37.9 * * \\
(0.6)\end{array}$ & $39.7 * *(0.6)$ \\
\hline $\begin{array}{l}\text { Eastern Europe origin (ref= } \\
\text { Western OECD countries) }\end{array}$ & $-7.0(7.4)$ & $\begin{array}{l}-9.8^{* *} \\
(3.0)\end{array}$ & - & - & - & - \\
\hline $\begin{array}{l}\text { Non-Islam Asia origin (ref= } \\
\text { Western OECD countries) }\end{array}$ & $\begin{array}{l}35.3^{* *} \\
(11.2)\end{array}$ & $\begin{array}{l}35.1 * * \\
(3.9)\end{array}$ & - & - & - & - \\
\hline $\begin{array}{l}\text { Islamic countries origin (ref }= \\
\text { Western OECD countries) }\end{array}$ & $\begin{array}{l}-38.2^{* *} \\
(9.3)\end{array}$ & $\begin{array}{l}-33.4^{* *} \\
(3.3)\end{array}$ & - & - & - & - \\
\hline $\begin{array}{l}\text { Sub-Saharan Africa origin (ref= } \\
\text { Western OECD countries) }\end{array}$ & $\begin{array}{l}-22.7 \\
(16.0)\end{array}$ & $\begin{array}{l}-22.1^{* *} \\
(5.0)\end{array}$ & - & - & - & - \\
\hline Female & $\begin{array}{l}30.6^{* *} \\
(1.7)\end{array}$ & $\begin{array}{l}31.7^{* *} \\
(1.8)\end{array}$ & $36.2^{* *}(1.9)$ & $\begin{array}{l}30.9 * * \\
(0.5)\end{array}$ & $\begin{array}{l}35.7 * * \\
(0.6)\end{array}$ & $39.2 * *(0.6)$ \\
\hline $\begin{array}{l}\text { Home language same as in } \\
\text { destination country }\end{array}$ & $\begin{array}{l}26.1^{* *} \\
(2.3)\end{array}$ & $\begin{array}{l}26.8^{* *} \\
(2.2)\end{array}$ & - & - & - & - \\
\hline $\begin{array}{l}\text { One parent migrant, other parent } \\
\text { native }\end{array}$ & $4.8(4.0)$ & $8.9^{* *}(4.1)$ & - & - & - & - \\
\hline Second generation migrant & $9.2 * *(1.9)$ & $7.9 * *(2.0)$ & - & - & - & - \\
\hline $\begin{array}{l}\text { Grade (destination country } \\
\text { centered) }\end{array}$ & $\begin{array}{l}40.5^{* *} \\
(1.6)\end{array}$ & $\begin{array}{l}46.0^{* *} \\
(1.6)\end{array}$ & - & $\begin{array}{l}42.9 * * \\
(0.7) \\
\end{array}$ & $\begin{array}{l}48.4^{* *} \\
(0.6)\end{array}$ & - \\
\hline \multicolumn{7}{|l|}{$\begin{array}{l}\text { Educational system } \\
\text { characteristics }\end{array}$} \\
\hline $\begin{array}{l}\text { Strongly stratified (ref }= \\
\text { Comprehensive) }\end{array}$ & $\begin{array}{l}-28.8^{*} \\
(15.4)\end{array}$ & $\begin{array}{l}-19.4 \\
(24.4)\end{array}$ & $-21.4(13.5)$ & $\begin{array}{l}-23.6 \\
(18.1)\end{array}$ & $\begin{array}{l}-20.0 \\
(18.5)\end{array}$ & $-0.5(10.3)$ \\
\hline $\begin{array}{l}\text { Moderately stratified (ref= } \\
\text { Comprehensive) }\end{array}$ & $\begin{array}{l}-25.3^{*} \\
(13.6)\end{array}$ & $-8.5(17.7)$ & $-32.2 *(16.4)$ & $\begin{array}{l}-22.3 \\
(13.1)\end{array}$ & $\begin{array}{l}-20.3 \\
(13.4) \\
\end{array}$ & $-12.8(12.5)$ \\
\hline Age of selection & $-3.1(2.8)$ & $-2.2(4.7)$ & - & $-3.5(3.5)$ & $-4.7(3.6)$ & - \\
\hline \multicolumn{7}{|l|}{$\begin{array}{l}\text { Interactions with educational } \\
\text { systems }\end{array}$} \\
\hline Parental ESCS* strongly stratified & $\begin{array}{l}-16.1^{* *} \\
(2.4) \\
\end{array}$ & $\begin{array}{l}-14.4^{* *} \\
(2.3) \\
\end{array}$ & $-2.3(2.5)$ & $\begin{array}{l}-15.1^{* *} \\
(0.8)\end{array}$ & $\begin{array}{l}-10.9^{* *} \\
(0.8)\end{array}$ & $-5.5^{* *}(0.9)$ \\
\hline $\begin{array}{l}\text { Parental ESCS* moderately } \\
\text { stratified }\end{array}$ & $\begin{array}{l}-14.1^{* *} \\
(3.2)\end{array}$ & $\begin{array}{l}-16.2^{* *} \\
(3.1)\end{array}$ & $-5.9(3.3)$ & $\begin{array}{l}-14.1^{* *} \\
(0.9)\end{array}$ & $\begin{array}{l}-5.9^{* *} \\
(0.9)\end{array}$ & $3.7^{* *}(0.9)$ \\
\hline \multicolumn{7}{|l|}{ Variation } \\
\hline Individual-level & $\begin{array}{l}4599.5 \\
(94.1)\end{array}$ & $\begin{array}{l}6687.1 \\
(102.5)\end{array}$ & $\begin{array}{l}7762.6 \\
(119.1)\end{array}$ & $\begin{array}{l}4447.3 \\
(23.9)\end{array}$ & $\begin{array}{l}6152.3 \\
(34.4)\end{array}$ & $\begin{array}{l}6707.3 \\
(35.3)\end{array}$ \\
\hline Track-within-school-level & $\begin{array}{l}1941.0 \\
(114.2)\end{array}$ & - & - & $\begin{array}{l}947.0 \\
(83.8)\end{array}$ & - & - \\
\hline School-level & - & - & - & $\begin{array}{l}1229.9 \\
(96.3)\end{array}$ & - & - \\
\hline Origin-country-level & $\begin{array}{l}000.0 \\
(00.0)\end{array}$ & - & - & - & - & - \\
\hline Destination-country-level & $\begin{array}{l}581.4 \\
(120.7)\end{array}$ & $\begin{array}{l}439.2 \\
(176.6)\end{array}$ & $\begin{array}{l}458.3 \\
(195.9)\end{array}$ & $\begin{array}{l}258.2 \\
(102.3) \\
\end{array}$ & $\begin{array}{l}287.1 \\
(106.0) \\
\end{array}$ & $\begin{array}{l}313.4 \\
(116.0)\end{array}$ \\
\hline Log likelihood & 98448 & 99279 & 100549 & 820492 & 836379 & 842626 \\
\hline
\end{tabular}

Source: PISA 2006; own computation 
Appendix E: The effects of individual characteristics, track characteristics, school characteristics, educational systems characteristics (model 6) on reading, math and science scores of immigrant and native students.

\begin{tabular}{|c|c|c|c|c|c|c|}
\hline & \multicolumn{3}{|c|}{ Immigrant students } & \multicolumn{3}{|c|}{ Native students } \\
\hline & Reading & Math & Science & Reading & Math & Science \\
\hline Constant & $\begin{array}{l}457.7 \\
(44.2) \\
\end{array}$ & $\begin{array}{l}502.9 \\
(38.4) \\
\end{array}$ & $\begin{array}{l}553.6 \\
(44.2) \\
\end{array}$ & $\begin{array}{l}483.4 \\
(59.8) \\
\end{array}$ & $\begin{array}{l}573.4 \\
(66.5) \\
\end{array}$ & $\begin{array}{l}692.8 \\
(65.0) \\
\end{array}$ \\
\hline \multicolumn{7}{|l|}{ Individual characteristics } \\
\hline Parental ESCS & $\begin{array}{l}25.0^{* *} \\
(2.1) \\
\end{array}$ & $\begin{array}{l}22.4^{* *} \\
(1.9)\end{array}$ & $\begin{array}{l}24.7^{* *} \\
(2.1)\end{array}$ & $\begin{array}{l}27.4^{* *} \\
(0.6)\end{array}$ & $\begin{array}{l}25.5^{* *} \\
(0.5)\end{array}$ & $\begin{array}{l}28.8^{* *} \\
(0.6)\end{array}$ \\
\hline $\begin{array}{l}\text { Eastern Europe origin (ref= Western } \\
\text { OECD countries) }\end{array}$ & $-8.2(6.8)$ & $\begin{array}{l}-15.9 * * \\
(5.9)\end{array}$ & $-11.1(6.8)$ & - & - & - \\
\hline $\begin{array}{l}\text { Non-Islam Asia origin (ref= Western } \\
\text { OECD countries) }\end{array}$ & $\begin{array}{l}18.6^{*} \\
(10.2)\end{array}$ & $\begin{array}{l}27.7 * * \\
(8.8)\end{array}$ & $19.1(10.2)$ & - & - & - \\
\hline $\begin{array}{l}\text { Islamic countries origin (ref= Western } \\
\text { OECD countries) }\end{array}$ & $\begin{array}{l}-35.3^{* *} \\
(8.4)\end{array}$ & $\begin{array}{l}-31.9 * * \\
(7.2)\end{array}$ & $\begin{array}{l}-36.0^{* *} \\
(8.4)\end{array}$ & - & - & - \\
\hline $\begin{array}{l}\text { Sub-Saharan Africa origin (ref= Western } \\
\text { OECD countries) }\end{array}$ & $\begin{array}{l}-15.0 \\
(14.2)\end{array}$ & $\begin{array}{l}-18.1 \\
(12.1)\end{array}$ & $\begin{array}{l}-14.3 \\
(14.3) \\
\end{array}$ & - & - & - \\
\hline Female & $\begin{array}{l}28.6^{* *} \\
(1.6) \\
\end{array}$ & $\begin{array}{l}-20.7^{* *} \\
(1.5) \\
\end{array}$ & $\begin{array}{l}-9.9 * * \\
(1.6) \\
\end{array}$ & $\begin{array}{l}30.6^{* *} \\
(0.5) \\
\end{array}$ & $\begin{array}{l}-19.3^{* *} \\
(0.5) \\
\end{array}$ & $\begin{array}{l}-8.9 * * \\
(0.6) \\
\end{array}$ \\
\hline $\begin{array}{l}\text { Home language same as in destination } \\
\text { country }\end{array}$ & $\begin{array}{l}24.2^{* *} \\
(2.2) \\
\end{array}$ & $\begin{array}{l}16.2^{* *} \\
(2.0) \\
\end{array}$ & $\begin{array}{l}23.0^{* *} \\
(2.2) \\
\end{array}$ & - & - & - \\
\hline One parent migrant, other parent native & $5.8(3.8)$ & $5.9(3.5)$ & $\begin{array}{l}10.2^{* *} \\
(3.8)\end{array}$ & - & - & - \\
\hline Second generation migrant & $9.3^{* *}(1.8)$ & $\begin{array}{l}8.0^{* *} \\
(1.7) \\
\end{array}$ & $7.5^{* *}(1.9)$ & - & - & - \\
\hline Grade (destination country centered) & $\begin{array}{l}31.8^{* *} \\
(1.8)\end{array}$ & $\begin{array}{l}33.6^{* *} \\
(1.7)\end{array}$ & $\begin{array}{l}31.7^{* *} \\
(1.8)\end{array}$ & $\begin{array}{l}41.1^{* *} \\
(0.7)\end{array}$ & $\begin{array}{l}42.0^{* *} \\
(0.7)\end{array}$ & $\begin{array}{l}39.2^{* *} \\
(0.7)\end{array}$ \\
\hline \multicolumn{7}{|l|}{$\begin{array}{l}\text { School-composition characteristics at } \\
\text { track-within-school }\end{array}$} \\
\hline Average ESCS & $\begin{array}{l}46.9^{* *} \\
(5.1)\end{array}$ & $\begin{array}{l}43.5^{* *} \\
(4.7)\end{array}$ & $\begin{array}{l}50.5^{* *} \\
(5.1)\end{array}$ & $\begin{array}{l}46.1^{* *} \\
(3.1)\end{array}$ & $\begin{array}{l}42.2^{* *} \\
(2.8)\end{array}$ & $\begin{array}{l}45.9^{* *} \\
(2.8)\end{array}$ \\
\hline $\begin{array}{l}\% \text { students from Eastern Europe (ref=\% } \\
\text { native students) }\end{array}$ & $0.4^{* *}(0.2)$ & $\begin{array}{l}0.3^{* *} \\
(0.1) \\
\end{array}$ & $0.3^{*}(0.2)$ & $-0.1(0.2)$ & $0.0(0.2)$ & $0.0(0.2)$ \\
\hline $\begin{array}{l}\text { \% students from non-Islamic Asia } \\
\text { (ref=\% native students) }\end{array}$ & $1.2 * *(0.2)$ & $\begin{array}{l}1.2^{* *} \\
(0.2)\end{array}$ & $1.3^{* *}(0.2)$ & $\begin{array}{l}0.5^{* *} \\
(0.2)\end{array}$ & $\begin{array}{l}0.8^{* *} \\
(0.2)\end{array}$ & $0.6^{* *}(0.2)$ \\
\hline $\begin{array}{l}\text { \% students from Islamic countries } \\
\text { (ref=\% native students) }\end{array}$ & $0.1(0.1)$ & $0.1(0.1)$ & $0.0(0.1)$ & $0.1(0.2)$ & $-0.2(0.1)$ & $-0.1(0.2)$ \\
\hline $\begin{array}{l}\% \text { students from western OECD } \\
\text { countries (ref }=\% \text { native students) }\end{array}$ & $0.0(0.1)$ & $0.0(0.1)$ & $0.2 *(0.1)$ & $-0.3(0.2)$ & $-0.2(0.1)$ & $-0.1(0.2)$ \\
\hline $\begin{array}{l}\text { \% students from Sub-Saharan Africa } \\
\text { (ref=\% native students) }\end{array}$ & $-0.2(0.4)$ & $0.0(0.4)$ & $-0.2(0.4)$ & $-0.5(0.4)$ & $-0.2(0.4)$ & $-0.3(0.4)$ \\
\hline ESCS diversity & $20.0(14.0)$ & $\begin{array}{ll}17.0 \\
(13.0)\end{array}$ & $23.1(13.9)$ & $-5.9(7.3)$ & $0.3(6.8)$ & $4.7(6.8)$ \\
\hline Ethnic diversity & $\begin{array}{l}-40.3^{* *} \\
(11.2)\end{array}$ & $\begin{array}{l}-34.4^{* *} \\
(10.4)\end{array}$ & $\begin{array}{l}-42.6^{* *} \\
(11.0)\end{array}$ & $\begin{array}{l}-16.2 \\
(10.9) \\
\end{array}$ & $\begin{array}{l}-30.6^{* *} \\
(10.1)\end{array}$ & $\begin{array}{l}-27.4^{* *} \\
(10.2)\end{array}$ \\
\hline \multicolumn{7}{|l|}{ Curriculum at track-within-school } \\
\hline Vocational (ref=general) & $\begin{array}{l}-54.1^{* *} \\
(4.6)\end{array}$ & $\begin{array}{l}-52.4^{* *} \\
(4.3) \\
\end{array}$ & $\begin{array}{l}-50.1^{* *} \\
(4.5) \\
\end{array}$ & $\begin{array}{l}-52.4^{* *} \\
(2.4) \\
\end{array}$ & $\begin{array}{l}-51.1^{* *} \\
(2.3) \\
\end{array}$ & $\begin{array}{l}-51.9 * * \\
(2.3) \\
\end{array}$ \\
\hline Higher secondary (ref=lower) & $-0.8(4.9)$ & $-0.4(4.5)$ & $0.9(4.9)$ & $-4.2(2.9)$ & $-3.7(2.8)$ & $-4.2(2.8)$ \\
\hline $\begin{array}{l}\text { Selective admittance (ref= Some } \\
\text { selective admittance) }\end{array}$ & $\begin{array}{l}18.0^{* *} \\
(2.8)\end{array}$ & $\begin{array}{l}18.9^{* *} \\
(2.6)\end{array}$ & $\begin{array}{l}19.5^{* *} \\
(2.7)\end{array}$ & $\begin{array}{l}16.4^{* *} \\
(2.3)\end{array}$ & $\begin{array}{l}18.4^{* *} \\
(2.1)\end{array}$ & $\begin{array}{l}18.4^{* *} \\
(2.1)\end{array}$ \\
\hline $\begin{array}{l}\text { Non selective admittance (ref= Some } \\
\text { selective admittance) }\end{array}$ & $1.0(2.4)$ & $1.2(2.2)$ & $0.8(2.4)$ & $-2.3(1.6)$ & $-0.9(1.5)$ & $-1.6(1.5)$ \\
\hline \multicolumn{7}{|l|}{ School characteristics } \\
\hline Teacher shortage & $-1.6(1.1)$ & $\begin{array}{l}-2.6^{* *} \\
(1.0) \\
\end{array}$ & $-1.5(1.1)$ & $\begin{array}{l}-4.8^{* *} \\
(0.8) \\
\end{array}$ & $\begin{array}{l}-4.2^{* *} \\
(0.7) \\
\end{array}$ & $\begin{array}{l}-4.1^{* *} \\
(0.7) \\
\end{array}$ \\
\hline Student/staff ratio & $0.8^{* *}(0.3)$ & $0.3(0.3)$ & $0.3(0.3)$ & $\begin{array}{l}0.5^{* *} \\
(0.2)\end{array}$ & $\begin{array}{l}0.4^{* *} \\
(0.2)\end{array}$ & $0.3(0.2)$ \\
\hline School in city (ref=towns) & $2.7(2.7)$ & $-0.3(2.5)$ & $1.5(2.7)$ & $-1.8(1.9)$ & $-2.8(1.8)$ & $-2.7(1.7)$ \\
\hline
\end{tabular}




\begin{tabular}{|c|c|c|c|c|c|c|}
\hline School in rural (ref=towns) & $2.7(2.7)$ & $4.1(2.5)$ & $5.9^{* *}(2.6)$ & $\begin{array}{l}5.6^{* *} \\
(1.7)\end{array}$ & $\begin{array}{l}6.6^{* *} \\
(1.6)\end{array}$ & $7.8^{* *}(1.5)$ \\
\hline School-size*100 & $0.7 * *(0.2)$ & $\begin{array}{l}0.7 * * \\
(0.2)\end{array}$ & $0.6^{* *}(0.2)$ & $\begin{array}{l}1.4 * * \\
(0.2)\end{array}$ & $\begin{array}{l}1.0^{* *} \\
(0.2)\end{array}$ & $1.0 * *(0.2)$ \\
\hline Private dependent (ref=Public school) & $-4.9(3.7)$ & $\begin{array}{l}-10.7^{* *} \\
(3.4) \\
\end{array}$ & $-6.0 *(3.6)$ & $\begin{array}{l}-7.4^{* *} \\
(2.5) \\
\end{array}$ & $\begin{array}{l}-4.9^{* *} \\
(2.2) \\
\end{array}$ & $\begin{array}{l}-3.6^{* *} \\
(2.2) \\
\end{array}$ \\
\hline Private independent (ref=Public school) & $-6.4(5.4)$ & $\begin{array}{l}--10.3^{* *} \\
(5.0)\end{array}$ & $-4.5(5.4)$ & $\begin{array}{l}-9.1^{* *} \\
(4.0)\end{array}$ & $-6.3(3.6)$ & $-5.7(3.5)$ \\
\hline \multicolumn{7}{|l|}{ Educational system characteristics } \\
\hline Strongly stratified (ref= Comprehensive) & $\begin{array}{l}-16.7 \\
(14.5)\end{array}$ & $\begin{array}{l}-17.0 \\
(12.5)\end{array}$ & $\begin{array}{l}-43.9 * * \\
(14.5)\end{array}$ & $-1.9(18.9)$ & $\begin{array}{l}-13.4 \\
(21.0)\end{array}$ & $\begin{array}{l}-24.8 \\
(20.5)\end{array}$ \\
\hline $\begin{array}{l}\text { Moderately stratified (ref= } \\
\text { Comprehensive) }\end{array}$ & $\begin{array}{l}-16.7 \\
(13.1)\end{array}$ & $\begin{array}{l}-16.0 \\
(11.4)\end{array}$ & $\begin{array}{l}-28.2^{* *} \\
(13.1)\end{array}$ & $\begin{array}{l}-16.8 \\
(14.1)\end{array}$ & $\begin{array}{l}-10.6 \\
(15.5)\end{array}$ & $\begin{array}{l}-17.1 \\
(15.2)\end{array}$ \\
\hline Age of selection & $-2.3(2.6)$ & $-1.8(2.3)$ & $\begin{array}{l}-6.1 * * \\
(2.6) \\
\end{array}$ & $-0.7(3.7)$ & $-4.6(4.1)$ & $-5.9(4.0)$ \\
\hline \multicolumn{7}{|l|}{ Interactions with educational systems } \\
\hline Parental ESCS* strongly stratified & $\begin{array}{l}-16.5^{* *} \\
(2.5)\end{array}$ & $\begin{array}{l}-14.0^{* *} \\
(2.3)\end{array}$ & $\begin{array}{l}-14.3^{* *} \\
(2.5)\end{array}$ & $\begin{array}{l}-16.4^{* *} \\
(0.8)\end{array}$ & $\begin{array}{l}-15.6^{* *} \\
(0.7)\end{array}$ & $\begin{array}{l}-17.4^{* *} \\
(0.8)\end{array}$ \\
\hline Parental ESCS* moderately stratified & $\begin{array}{l}-16.5^{* *} \\
(3.3) \\
\end{array}$ & $\begin{array}{l}-17.3^{* *} \\
(3.1) \\
\end{array}$ & $\begin{array}{l}-15.9^{* *} \\
(3.3) \\
\end{array}$ & $\begin{array}{l}-15.9^{* *} \\
(0.9) \\
\end{array}$ & $\begin{array}{l}-10.8^{* *} \\
(0.8) \\
\end{array}$ & $\begin{array}{l}-13.7^{* *} \\
(0.9) \\
\end{array}$ \\
\hline Average ESCS* strongly stratified & $\begin{array}{l}19.5^{* *} \\
(6.2) \\
\end{array}$ & $\begin{array}{l}18.4^{* *} \\
(5.7) \\
\end{array}$ & $10.1(6.1)$ & $-2.6(3.7)$ & $-3.8(3.4)$ & $\begin{array}{l}-8.7^{* *} \\
(3.4)\end{array}$ \\
\hline Average ESCS* moderately stratified & $-11.0(8.3)$ & $-5.8(7.7)$ & $\begin{array}{l}-17.7^{* *} \\
(8.3)\end{array}$ & $6.4(4.3)$ & $2.1(4.0)$ & $0.4(3.9)$ \\
\hline Higher secondary* strongly stratified & $\begin{array}{l}16.3^{* *} \\
(6.5)\end{array}$ & $\begin{array}{l}11.4^{*} \\
(6.0)\end{array}$ & $\begin{array}{l}13.0^{* *} \\
(6.4)\end{array}$ & $\begin{array}{l}11.9 * * \\
(3.9)\end{array}$ & $\begin{array}{l}16.0^{* *} \\
(3.8)\end{array}$ & $\begin{array}{l}18.2^{* *} \\
(3.8)\end{array}$ \\
\hline Higher secondary* moderately stratified & $\begin{array}{l}32.7 * * \\
(9.8) \\
\end{array}$ & $\begin{array}{l}27.8^{* *} \\
(9.0) \\
\end{array}$ & $\begin{array}{l}20.3^{* *} \\
(9.7) \\
\end{array}$ & $\begin{array}{l}25.1^{* *} \\
(8.1) \\
\end{array}$ & $\begin{array}{l}17.1^{* *} \\
(7.7)\end{array}$ & $6.6(7.8)$ \\
\hline \multicolumn{7}{|l|}{ Reproduction } \\
\hline Parental ESCS* average ESCS & $-0.5(1.8)$ & $\begin{array}{l}3.5^{* *} \\
(1.6) \\
\end{array}$ & $3.1^{* *}(1.8)$ & $-1.1 *(0.6)$ & $\begin{array}{l}1.5^{* *} \\
(0.6)\end{array}$ & $1.6^{* *}(0.6)$ \\
\hline \multicolumn{7}{|l|}{ Variation } \\
\hline Individual-level & $\begin{array}{l}4516.2 \\
(89.0)\end{array}$ & $\begin{array}{l}3904.3 \\
(76.9) \\
\end{array}$ & $\begin{array}{l}4663.7 \\
(91.0) \\
\end{array}$ & $\begin{array}{l}4447.3 \\
(23.9) \\
\end{array}$ & $\begin{array}{l}4077.0 \\
(21.9)\end{array}$ & $\begin{array}{l}5000.0 \\
(26.9)\end{array}$ \\
\hline Track-within-school-level & $\begin{array}{l}917.1 \\
(82.8)\end{array}$ & $\begin{array}{l}792.0 \\
(71.6)\end{array}$ & $\begin{array}{l}793.2 \\
(80.2)\end{array}$ & $\begin{array}{l}307.7 \\
(41.9)\end{array}$ & $\begin{array}{l}307.2 \\
(39.5)\end{array}$ & $\begin{array}{l}268.0 \\
(40.6)\end{array}$ \\
\hline School-level & - & - & - & $\begin{array}{l}759.0 \\
(50.4)\end{array}$ & $\begin{array}{l}552.3 \\
(44.6)\end{array}$ & $\begin{array}{l}513.3 \\
(44.9)\end{array}$ \\
\hline Origin-country-level & $\begin{array}{l}000.0 \\
(00.0) \\
\end{array}$ & $\begin{array}{l}000.0 \\
(00.0)\end{array}$ & $\begin{array}{l}291.4 \\
(1640.2)\end{array}$ & - & - & - \\
\hline Destination-country-level & $\begin{array}{l}444.6 \\
(91.7) \\
\end{array}$ & $\begin{array}{l}312.0 \\
(67.0) \\
\end{array}$ & $\begin{array}{l}159.0 \\
(1639.6) \\
\end{array}$ & $\begin{array}{l}279.6 \\
(107.1) \\
\end{array}$ & $\begin{array}{l}354.1 \\
(133.6) \\
\end{array}$ & $\begin{array}{l}337.2 \\
(127.2) \\
\end{array}$ \\
\hline Log likelihood & 97314 & 96060 & 97415 & 818466 & 811887 & 825911 \\
\hline
\end{tabular}

Source: PISA 2006; own computation 
Appendix F: The effects of individual characteristics and educational systems characteristics (model 6) on reading scores of immigrant and native students with the measured and countrycentered track-level

\begin{tabular}{|c|c|c|c|c|}
\hline & \multicolumn{2}{|c|}{ Immigrant students } & \multicolumn{2}{|c|}{ Native students } \\
\hline & $\begin{array}{l}\text { Measured track- } \\
\text { level }\end{array}$ & $\begin{array}{l}\text { Centered track- } \\
\text { level }\end{array}$ & $\begin{array}{l}\text { Measured track- } \\
\text { level }\end{array}$ & $\begin{array}{l}\text { Centered track- } \\
\text { level }\end{array}$ \\
\hline Constant & $457.7(44.2)$ & $457.2(45.6)$ & $483.4(59.8)$ & $463.6(61.7)$ \\
\hline \multicolumn{5}{|l|}{ Individual characteristics } \\
\hline Parental ESCS & $25.0 * *(2.1)$ & $24.9 * *(2.1)$ & $27.4 * *(0.6)$ & $27.4 * *(0.6)$ \\
\hline $\begin{array}{l}\text { Eastern Europe origin (ref= Western OECD } \\
\text { countries) }\end{array}$ & $-8.2(6.8)$ & $-6.9(7.0)$ & - & - \\
\hline $\begin{array}{l}\text { Non-Islamic Asia origin (ref= Western OECD } \\
\text { countries) }\end{array}$ & $18.6 *(10.2)$ & $19.6 *(10.5)$ & - & - \\
\hline $\begin{array}{l}\text { Islamic countries origin (ref= Western OECD } \\
\text { countries) }\end{array}$ & $-35.3 * *(8.4)$ & $-35.2 * *(8.6)$ & - & - \\
\hline $\begin{array}{l}\text { Sub-Saharan Africa origin (ref= Western } \\
\text { OECD countries) }\end{array}$ & $-15.0(14.2)$ & $-14.6(14.7)$ & - & - \\
\hline Female & $28.6^{* *}(1.6)$ & $28.6^{* *}(1.6)$ & $30.6^{* *}(0.5)$ & $30.6^{* *}(0.6)$ \\
\hline Home language same as in destination country & $24.2 * *(2.2)$ & $24.2 * *(2.2)$ & - & - \\
\hline One parent migrant, other parent native & $5.8(3.8)$ & $5.7(3.8)$ & - & - \\
\hline Second generation migrant & $9.3^{* *}(1.8)$ & $9.4^{* *}(1.8)$ & - & - \\
\hline Grade (destination country centered) & $31.8 * *(1.8)$ & $33.0 * *(1.8)$ & $41.1^{* *}(0.7)$ & $40.9 * *(0.7)$ \\
\hline \multicolumn{5}{|l|}{$\begin{array}{l}\text { School-composition characteristics at track- } \\
\text { within-school }\end{array}$} \\
\hline Average ESCS & $46.9 * *(5.1)$ & $46.9 * *(5.1)$ & $46.1^{* *}(3.1)$ & $46.3^{* *}(3.0)$ \\
\hline $\begin{array}{l}\text { \% students from Eastern Europe (ref }=\% \text { native } \\
\text { students) }\end{array}$ & $0.4^{* *}(0.2)$ & $0.4^{* *}(0.2)$ & $-0.1(0.2)$ & $-0.1(0.2)$ \\
\hline $\begin{array}{l}\% \text { students from non-Islamic Asia (ref }=\% \\
\text { native students) }\end{array}$ & $1.2^{* *}(0.2)$ & $1.2^{* *}(0.2)$ & $0.5^{* *}(0.2)$ & $0.6^{* *}(0.2)$ \\
\hline $\begin{array}{l}\% \text { students from Islamic countries (ref }=\% \\
\text { native students) }\end{array}$ & $0.1(0.1)$ & $0.1(0.1)$ & $0.1(0.2)$ & $0.1(0.2)$ \\
\hline $\begin{array}{l}\text { \% students from western OECD countries } \\
\text { (ref=\% native students) }\end{array}$ & $0.0(0.1)$ & $0.0(0.1)$ & $-0.3(0.2)$ & $-0.3(0.2)$ \\
\hline $\begin{array}{l}\text { \% students from Sub-Saharan Africa (ref }=\% \\
\text { native students) }\end{array}$ & $-0.2(0.4)$ & $-0.2(0.4)$ & $-0.5(0.4)$ & $-0.5(0.4)$ \\
\hline ESCS diversity & $20.0(14.0)$ & $18.8(14.0)$ & $-5.9(7.3)$ & $-6.2(7.2)$ \\
\hline Ethnic diversity & $-40.3 * *(11.2)$ & $-40.9 * *(11.2)$ & $-16.2(10.9)$ & $-16.6(10.8)$ \\
\hline \multicolumn{5}{|l|}{ Curriculum at track-within-school } \\
\hline Vocational (ref=general) & $-54.1 * *(4.6)$ & $-48.7 * *(4.5)$ & $-52.4 * *(2.4)$ & $-51.0 * *(2.3)$ \\
\hline Higher secondary (ref=lower) & $-0.8(4.9)$ & $-1.0(2.6)$ & $-4.2(2.9)$ & $-2.6(1.5)$ \\
\hline $\begin{array}{l}\text { Selective admittance (ref= Some selective } \\
\text { admittance) }\end{array}$ & $18.0 * *(2.8)$ & $18.5^{* *}(2.8)$ & $16.4^{* *}(2.3)$ & $16.3^{* *}(2.3)$ \\
\hline $\begin{array}{l}\text { Non selective admittance (ref= Some selective } \\
\text { admittance) }\end{array}$ & $1.0(2.4)$ & $1.0(2.4)$ & $-2.3(1.6)$ & $-2.2(1.6)$ \\
\hline \multicolumn{5}{|l|}{ School characteristics } \\
\hline Teacher shortage & $-1.6(1.1)$ & $-1.6(1.1)$ & $-4.8^{* *}(0.8)$ & $-4.8^{* *}(0.8)$ \\
\hline Student/staff ratio & $0.8^{* *}(0.3)$ & $0.7^{* *}(0.3)$ & $0.5^{* *}(0.2)$ & $0.6^{* *}(0.2)$ \\
\hline School in city (ref=towns) & $2.7(2.7)$ & $2.6(2.7)$ & $-1.8(1.9)$ & $-1.9(1.9)$ \\
\hline School in rural (ref=towns) & $2.7(2.7)$ & $2.6(2.7)$ & $5.6^{* *}(1.7)$ & $5.6^{* *}(1.7)$ \\
\hline School-size*100 & $0.7^{* *}(0.2)$ & $0.7^{* *}(0.2)$ & $1.4^{* *}(0.2)$ & $1.3^{* *}(0.2)$ \\
\hline Private dependent (ref=Public school) & $-4.9(3.7)$ & $-5.3(3.7)$ & $-7.4^{* *}(2.5)$ & $-7.3^{* *}(2.5)$ \\
\hline Private independent (ref=Public school) & $-6.4(5.4)$ & $-6.9(5.4)$ & $-9.1^{* *}(4.0)$ & $-8.5^{* *}(3.9)$ \\
\hline \multicolumn{5}{|l|}{ Educational system characteristics } \\
\hline Strongly stratified (ref= Comprehensive) & $-16.7(14.5)$ & $-10.9(15.0)$ & $-1.9(18.9)$ & $8.7(19.4)$ \\
\hline Moderately stratified (ref= Comprehensive) & $-16.7(13.1)$ & $-1.1(12.7)$ & $-16.8(14.1)$ & $-3.3(13.9)$ \\
\hline Age of selection & $-2.3(2.6)$ & $-2.3(2.7)$ & $-0.7(3.7)$ & 0.4 (3.8) \\
\hline
\end{tabular}




\begin{tabular}{|l|l|l|l|l|}
\hline Interactions with educational systems & & & & \\
\hline Parental ESCS* strongly stratified & $-16.5^{* *}(2.5)$ & $-16.4^{* *}(2.5)$ & $-16.4^{* *}(0.8)$ & $-16.4^{* *}(0.8)$ \\
\hline Parental ESCS* moderately stratified & $-16.5^{* *}(3.3)$ & $-16.4^{* *}(3.3)$ & $-15.9^{* *}(0.9)$ & $-15.9^{* *}(0.9)$ \\
\hline Average ESCS* strongly stratified & $19.5^{* *}(6.2)$ & $21.3^{* *}(6.2)$ & $-2.6(3.7)$ & $-4.56(4.2)$ \\
\hline Average ESCS* moderately stratified & $-11.0(8.3)$ & $-8.8(8.6)$ & $6.4(4.3)$ & $4.2(4.4)$ \\
\hline Higher secondary* strongly stratified & $16.3^{* *}(6.5)$ & $4.3(3.3)$ & $11.9^{* *}(3.9)$ & $8.1^{* *}(2.0)$ \\
\hline Higher secondary* moderately stratified & $32.7^{* *}(9.8)$ & $16.7^{*}(5.1)$ & $25.1^{* *}(8.1)$ & $18.7^{* *}(3.9)$ \\
\hline Reproduction & & & & $-1.1^{*}(0.6)$ \\
\hline Parental ESCS* average ESCS & $-0.5(1.8)$ & $-0.4(1.8)$ & & $-1.2^{*}(0.6)$ \\
\hline Variation & & & $4447.3(23.9)$ & $4447.4(23.9)$ \\
\hline Individual-level & $4516.2(89.0)$ & $4511.0(88.9)$ & $307.7(41.9)$ & $309.0(41.9)$ \\
\hline Track-within-school-level & $917.1(82.8)$ & $926.0(83.1)$ & $759.0(50.4)$ & $746.2(50.1)$ \\
\hline School-level & - & - & - & - \\
\hline Origin-country-level & $000.0(00.0)$ & $000.0(00.0)$ & - & $299.3(114.2)$ \\
\hline Destination-country-level & $444.6(91.7)$ & $484.6(98.8)$ & $279.6(107.1)$ & 818444 \\
\hline Log likelihood & 97314 & 97321 & 818466 & \\
\hline
\end{tabular}

Source: PISA 2006; own computation 
Appendix G: estimation of educational performance of first generation immigrant students from Western OECD countries with different parental ESCS, in schools with different ESCS composition and track-level and in different educational systems (model 6 of table 2). The scores of the immigrant students from Eastern Europe, non-Islamic Asia, Islamic countries and Sub-Saharan African countries can be obtained by changing the scores with $-8.2,+18.6,-35.3$ and -15.0 respectively. The scores of second-generation immigrant students should be changed with +9.3 , of those who use the same language as the destination country with +24.2 and those with mixed parents with +5.8 .

\section{Constant}

\section{School ESCS}

Vocational

higher secondary

Parent ESCS

strongly stratified

moderately stratified

higher*strongly

higher* moderately

School ESCS* strongly

School ESCS*moderately

Parent ESCS* strongly

Parent ESCS*moderately

Parent ESCS* school ESCS

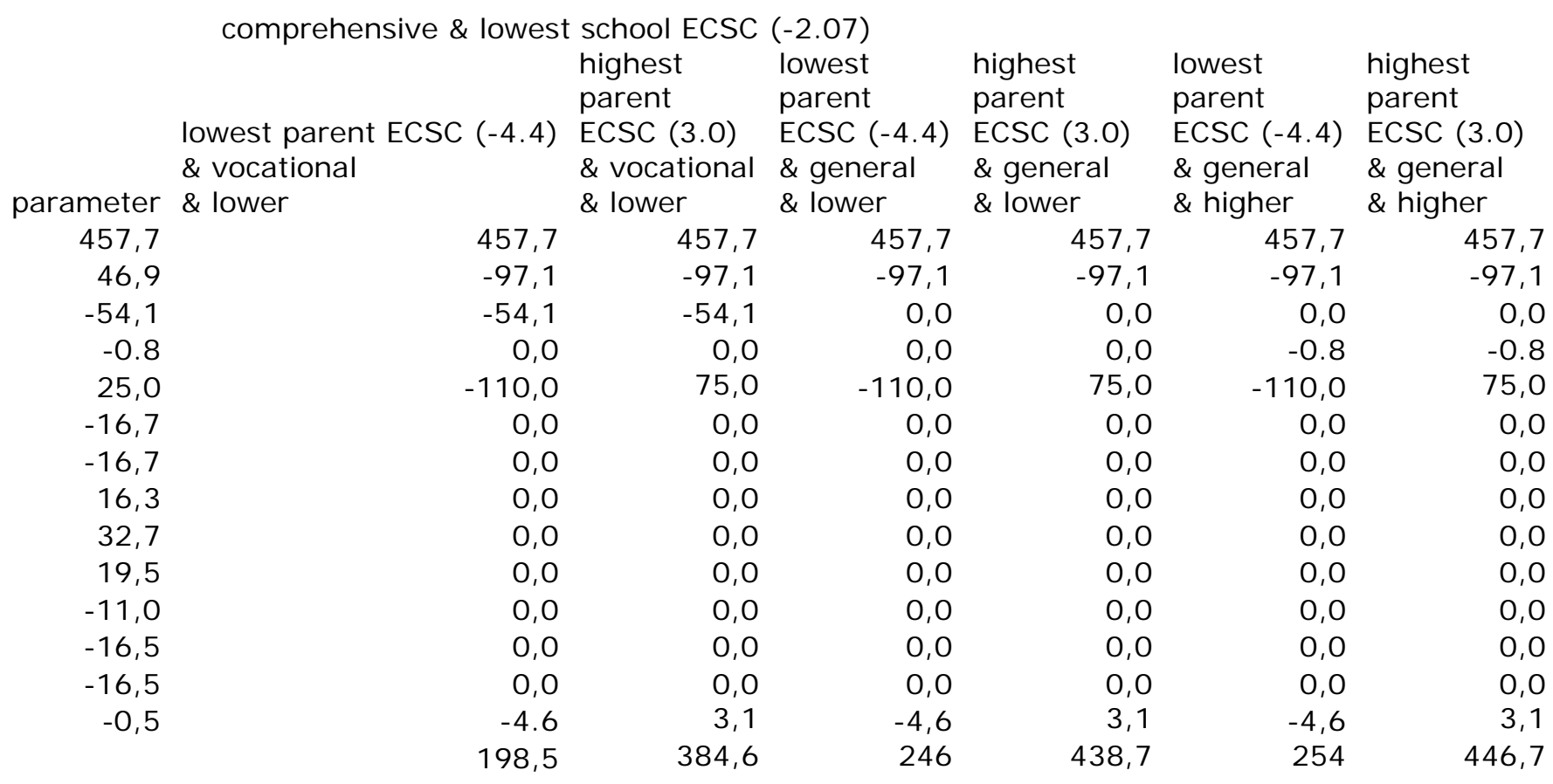


Constant

School ESCS

Vocational

higher secondary

Parent ESCS

strongly stratified

moderately stratified

higher*strongly

higher* moderately

School ESCS*strongly

School ESCS* moderately

Parent ESCS* strongly

Parent ESCS*moderately

Parent ESCS*school ESCS comprehensive \& highest school ECSC (1.64)

lowest parent ECSC (-4.4)

$\&$ vocational

parameter \& lower

457,7

46,9

$-54,1$

$-0.8$

25,0

$-16,7$

$-16,7$

16,3

32,7

19,5

$-11,0$

$-16,5$

$-16,5$

$-0,5$ highest lowest

parent parent

$\operatorname{ECSC}(-4.4)$

$\&$ vocational \& gener
$\&$ lower highest

parent

$\operatorname{ECSC}(3.0)$

$\&$ general

$\&$ lower

457,7

76,9

$-54,1$

457,7

76,9

$-54,1$

0,0

0,0

75,0

0,0

0,0

0,0

0,0

0,0

0,0

0,0

0,0

$-2,5$

$374,1 \quad 553 \quad 428,2$
0,0

0,0

$-110,0$

0,0

0,0

0,0

0,0

0,0

0,0

0,0

0,0

3,6 $\begin{array}{lll}374,1 & 553 & 428,2\end{array}$
457,7

76,9

0,0

0,0

75,0

0,0

0,0

0,0

0,0

0,0

0,0

0,0

0,0

$-2,5$

607,1 lowest highest

parent parent

$\operatorname{ECSC}(-4.4) \quad \operatorname{ECSC}(3.0)$

$\&$ general \& general

\& higher \& higher

457,7

76,9

0,0

$-0,8$

75,0

0,0

0,0

0,0

0,0

0,0

0,0

0,0

0,0

$-2,5$

606,3 


\section{Constant}

\section{School ESCS}

Vocational

higher secondary

Parent ESCS

strongly stratified

moderately stratified

higher*strongly

higher* moderately

School ESCS*strongly

School ESCS* moderately

Parent ESCS* strongly

Parent ESCS*moderately

Parent ESCS*school ESCS
Moderately stratified \& lowest school ECSC (-2.07)

lowest parent ECSC (-4.4)

$\&$ vocational

parameter \& lower

457,7

46,9

$-54,1$

$-0.8$

25,0

$-16,7$

$-16,7$

16,3

32,7

19,5

$-11,0$

$-16,5$

$-16,5$

$-0,5$

$\&$ lower highest

parent

lowest

parent
$\operatorname{ECSC}(3.0)$
$\&$ vocational $\&$ lower

$\operatorname{ECSC}(-4.4)$ highest

parent

$\operatorname{ECSC}(3.0)$

$\&$ general

$\&$ lower

457,7

$-97,1$

$-54,1$

0,0

$-110,0$

0,0

$-16,7$

0,0

0,0

0,0

5,0

0,0

72,6

$-4.6$

259,4
457,7

$-97,1$

$-54,1$

0,0

75,0

0,0

$-16,7$

0,0

0,0

0,0

5,0

0,0

$-49,5$

3,1

323,4
457,7
$-97,1$

0,0

0,0

$-110,0$

0,0

$-16,7$

0,0

0,0

0,0

5,0

0,0

72,6

$-4,6$

306,9
457,7

$-97,1$

0,0

0,0

75,0

0,0

$-16,7$

0,0

0,0

0,0

5,0

0,0

$-49,5$

3,1

377,5 lowest highest

parent parent

$\operatorname{ECSC}(-4.4) \quad \operatorname{ECSC}(3.0)$

$\&$ general \& general $\&$ higher \& higher

457,7

$-97,1$

457,7

$-97,1$

0,0

6,2

75,0

110,0

0,0

$-16,7$

0,0

32,7

0,0

5,0

0,0

$-49,5$

3,1

416, 4 
Constant

School ESCS

Vocational

higher secondary

Parent ESCS

strongly stratified

moderately stratified

higher*strongly

higher* moderately

School ESCS* strongly

School ESCS* moderately

Parent ESCS* strongly

Parent ESCS*moderately

Parent ESCS*school ESCS
Moderately stratified \& highest school ECSC (1.64)

lowest parent ECSC (-4.4)

$\&$ vocational

parameter \& lower

457,7

46,9

$-54,1$

$-0.8$

25,0

$-16,7$

$-16,7$

16,3

32,7

19,5

$-11,0$

$-16,5$

$-16,5$

$-0,5$ highest

parent

lowest

parent

$\&$ vocational $\&$ general

highest

parent

$\operatorname{ECSC}(3.0)$

$\&$ general

$\&$ lower

$\&$ lower

457,7

457,7

76,9

$-54,1$

76,9

76,9

$-54,1$

0,0

0,0

0,0

0,0

$-110,0$

0,0

0,0

$-16,7$

0,0

0,0

0,0

$-18,0$

0,0

72,6

3,6

412

$-16,7$

$-16,7$

0,0

0,0

0,0

$-18,0$

$-18,0$

0,0

72,6

3,6

466,1

$-2,5$

468,8
457,

45,9
0,0

$\begin{array}{ll}\text { lowest } & \text { highest } \\ \text { parent } & \text { parent } \\ \text { ECSC (-4.4) } & \text { ECSC (3.0) } \\ \& \text { general } & \& \text { general } \\ \& \text { higher } & \& \text { higher }\end{array}$

457,7

76,9

76,9

0,0

0,0
75,0

75,0

0,0

$-16,7$

0,0

0,0

0,0

$-18,0$

0,0

$-49,5$

$-2,5$

522,9

0,0

$-0,8$

$-0,8$

$-110,0$

75,0

0,0

0,0

$-16,7$

0,0

0,0

32,7

0,0

$-18,0$

0,0

$-49,5$

0,0

$-2,5$

554,8 


\section{Constant}

\section{School ESCS}

Vocational

higher secondary

Parent ESCS

strongly stratified

moderately stratified

higher*strongly

higher* moderately

School ESCS*strongly

School ESCS* moderately

Parent ESCS* strongly

Parent ESCS*moderately

Parent ESCS*school ESCS strongly stratified \& lowest school ECSC (-2.07)

highest

lowest

lowest parent ECSC (-4.4)

$\&$ vocational

parameter \& lower

457,7

46,9

$-54,1$

$-0,8$

25,0

$-16,7$

$-16,7$

16,3

32,7

19,5

$-11,0$

$-16,5$

$-16,5$

$-0,5$ parent

ECSC (3.0)

$\&$ lower

parent

$\operatorname{ECSC}(-4.4)$

$\&$ general

$\&$ lower

457,7

457,7

$-97,1$

$-54,1$

0,0

$-110,0$

$-16,7$

0,0

0,0

0,0

$-40,4$

0,0

72,6

0,0

$-4.6$

214

$-54,1$
0,0

75,0

$-16,7$

0,0

0,0

0,0

$-40,4$

0,0

$-49,5$

0,0

3,1

278 highest

parent

$\operatorname{ECSC}(3.0)$

$\&$ general

$\&$ lower

457,7

$-97,1$

0,0

457,7

457,7
$-97,1$

0,0

0,0

75,0

$-16,7$

$-110,0$

$-16,7$

0,0

0,0

0,0
$-40,4$

0,0

72,6

0,0

$-4,6$

261,5

0,0

0,0

$-40,4$

0,0
$-49,5$

0,0
3,1

332,1 lowest highest

parent parent

$\operatorname{ECSC}(-4.4) \quad \operatorname{ECSC}(3.0)$

$\&$ general \& general
$\&$ higher
$\&$ higher

457,7

457,7

$-97,1$

$-97,1$

0,0

0,0

$-0,8$

$-0,8$

$-110,0$

75,0

$-16,7$

0,0

16,3

16,3

0,0

0,0
$-40,4$

$-40,4$

0,0

0,0

$-49,5$

0,0

$-4,6$

277

347,6 


\section{Constant}

School ESCS

Vocational

higher secondary

Parent ESCS

strongly stratified

moderately stratified

higher*strongly

higher* moderately

School ESCS* strongly

School ESCS* moderately

Parent ESCS* strongly

Parent ESCS*moderately

Parent ESCS*school ESCS strongly \& highest school ECSC (1.64)

highest lowest

parent

lowest parent ECSC (-4.4)

$\&$ vocational

parameter \& lower

457,7

46,9

$-54,1$

$-0.8$

25,0

$-16,7$

$-16,7$

16,3

32,7

19,5

$-11,0$

$-16,5$

$-16,5$

$-0,5$ parent

parent

ECSC $(-4.4)$

$\&$ vocational

$\&$ lower

$\&$ lower

457,7

76,9

$-54,1$

$-54,1$

0,0

$-110,0$

$-16,7$

0,0

0,0

0,0

32,0

0,0

72,6

0,0

3,6

462

75,0

$-16,7$

0,0

0,0

0,0

32,0

0,0

$-49,5$

0,0

$-2,5$

518,8 highest

parent

$\operatorname{ECSC}$ (3.0)

$\&$ general

$\&$ lower

457,7

76,9

0,0

0,0

$-110,0$

$-16,7$

0,0

0,0

0,0

32,0

0,0

72,6

0,0

3,6

516,1 lowest highest

parent parent

$\operatorname{ECSC}(-4.4) \quad \operatorname{ECSC}(3.0)$

$\&$ general \& general

$\&$ higher \& higher

457,7

457,7

76,9

457,7

0,0

76,9

0,0

$-0,8$

$-0,8$

$-110,0$

75,0

75,0

$-16,7$

$-16,7$

$-16,7$

0,0

0,0

0,0

0,0

16,3

16,3

32,0

0,0
32,0

0,0

32,0

0,0

$-49,5$

0,0

0,0

$-49,5$

72,6

0,0

$-2,5$

572,9

3,6

531,6

$-2,5$

588,4 
Appendix H: estimation of educational performance of comparable native students with different parental ESCS, in schools with different ESCS composition and track-level and in different educational systems (model 6 of table 1).

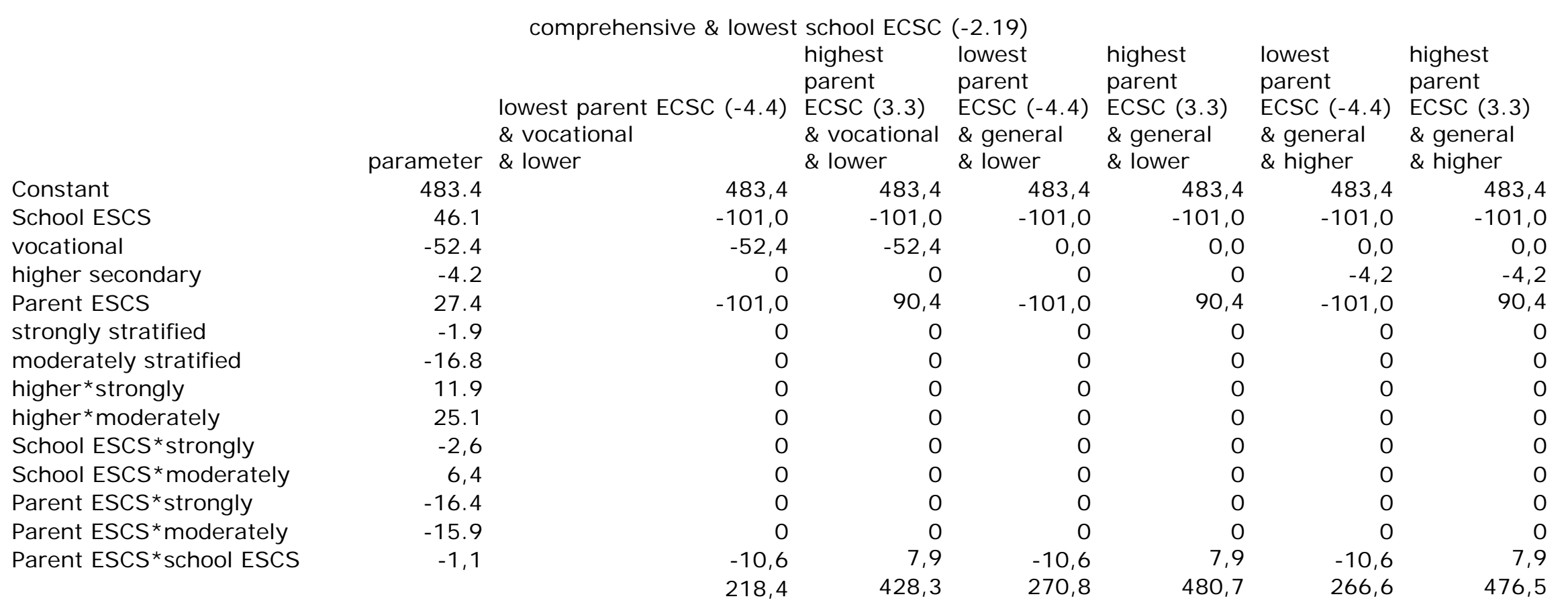


constant

School ESCS

vocational

higher secondary

Parent ESCS

strongly stratified

moderately stratified

higher*strongly

higher* moderately

School ESCS*strongly

School ESCS* moderately

Parent ESCS* strongly

Parent ESCS*moderately

Parent ESCS* school ESCS

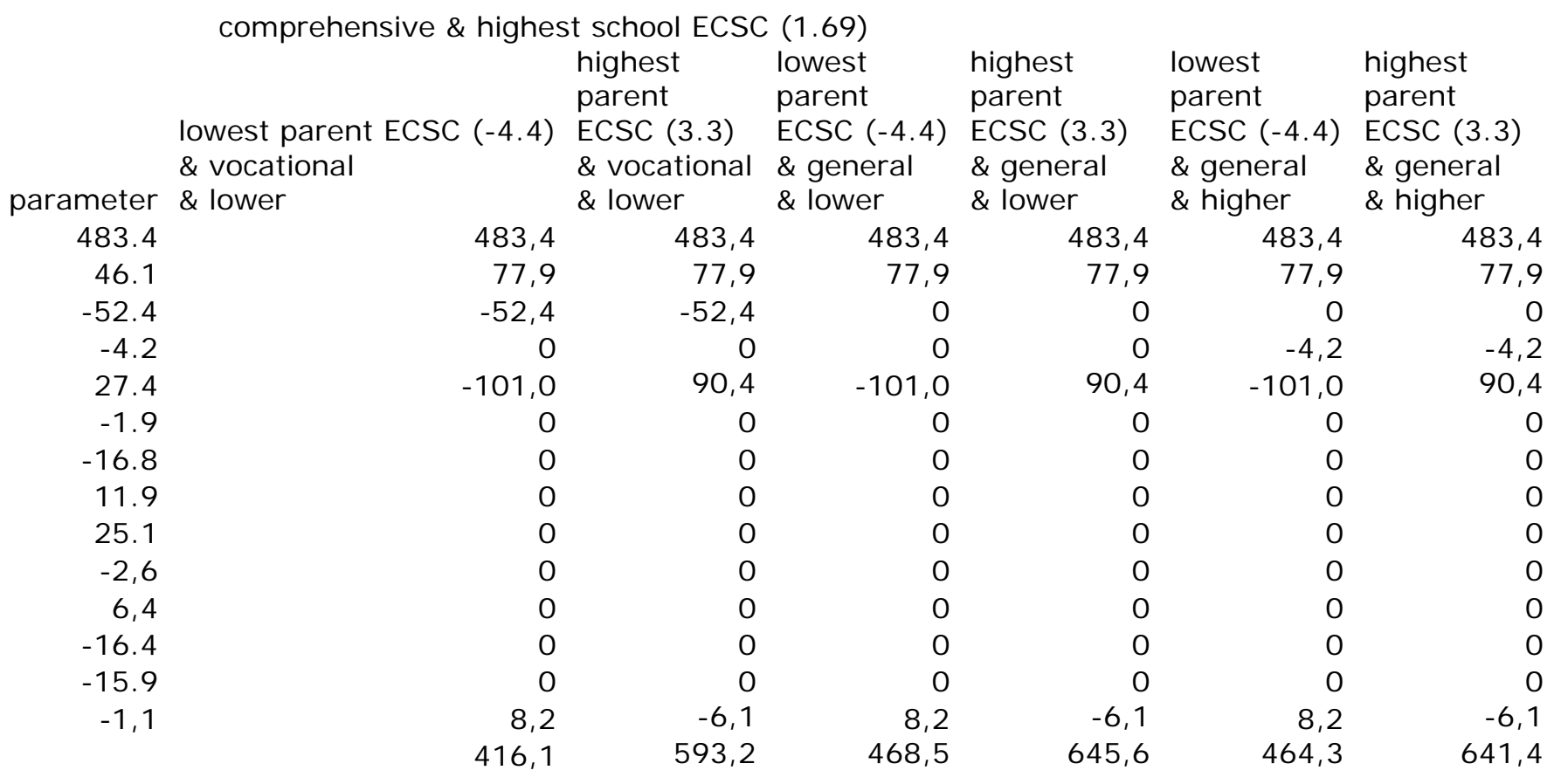


constant

\section{School ESCS}

vocational

higher secondary

Parent ESCS

strongly stratified

moderately stratified

higher*strongly

higher* moderately

School ESCS* strongly

School ESCS* moderately

Parent ESCS* strongly

Parent ESCS*moderately

Parent ESCS*school ESCS
Moderately stratified \& lowest school ECSC (-2.19)

highest

parent

lowest

parent

highest

lowest parent ECSC (-4.4)

$\&$ vocational

parameter \& lower

\& vocational $\&$ ECSC (-4.4)

parent

$\&$ genera
$\&$ lower

$\&$ lower

483,4

483,4

46.1

$-52.4$

$-4.2$

27.4

$-1.9$

$-16.8$

11.9

25.1

$-2,6$

6,4

$-16.4$

$-15.9$

$-1,1$
$-101,0$

$-52,4$

$-101,0$

$-101,0$
0

$-16,8$

0

25,1

0

$-14,0$

70,0

$-10,6$

282,7
483,4

$-101,0$

$-52,4$

0

90,4

$-16,8$

0

25,1

0
$-14,0$

0

$-52,5$

7,9

370,1
$-101,0$

0,0

0

$-101,0$
0

$-16,8$

0

25, 1

0

$-14,0$

70,0

$-10,6$

335,1 lowest

parent

$\operatorname{ECSC}(-4.4) \quad \operatorname{ECSC}(3.3)$

$\&$ general \& general

$\&$ higher \& higher

483,4

$-101,0$

483,4

$-101,0$

483,4

$-101,0$

0,0

0,0

0,0

$00-4,2$

$-101,0$

$-4,2$

90,4

0

0
$-16,8$

$-16,8$

$-16,8$

25, 1

25,1
0

$-14,0$

0

$-52,5$

7,9

422,5

0

25, 1

$-14,0$

0

70,0

$-10,6$

330,9

418,3 
constant

School ESCS

vocational

higher secondary

Parent ESCS

strongly stratified

moderately stratified

higher*strongly

higher* moderately

School ESCS* strongly

School ESCS* moderately

Parent ESCS* strongly

Parent ESCS*moderately

Parent ESCS* school ESCS
Moderately stratified \& highest school ECSC (1.69)

highest

parent

lowest

lowest parent ECSC (-4.4)

$\&$ vocational

parameter \& lower

ECSC (3.3) $\operatorname{ECSC}(-4.4)$

\& genera

$\&$ lower

highest

parent

$\operatorname{ECSC}(3.3)$

$\&$ general

$\&$ lower

46.1

$-52.4$

$-4.2$

27.4

$-1.9$

$-16.8$

11.9

25.1

$-2,6$

6,4

$-16.4$

$-15.9$

$-1,1$
483,4

483,4

77,9

77,9

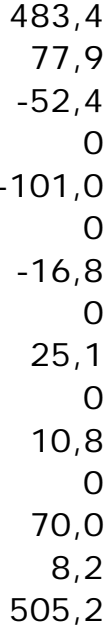

$-52,4$

0

90,4

0

0
$-16,8$

101,0
0

$-16,8$

0

25,1
0

10,8

0

$-52,5$

$-6,1$

559,8
0

25,1

0

10,8

70,0

8,2

557,6
483,4

77,9

0

90,4

$-16,8$

0

25,1

0

10,8

0

$-52,5$
$-6,1$

612,2 lowest highest

parent parent

$\operatorname{ECSC}(-4.4) \quad \operatorname{ECSC}(3.3)$

$\&$ general \& general

$\&$ higher \& higher

$77,9 \quad 77,9$

0

$\begin{array}{rr}-4,2 & -4,2 \\ -101,0 & 90,4\end{array}$

$\begin{array}{rr}101,0 & 90,4 \\ 0 & 0\end{array}$

$-16,8 \quad-16,8$

$0 \quad 0$

$25,1 \quad 25,1$

$10,8 \quad 10,8$

$0-10,8$

$70,0 \quad-52,5$

$8,2 \quad-6,1$

$553,4 \quad 608$ 
constant

School ESCS

vocational

higher secondary

Parent ESCS

strongly stratified

moderately stratified

higher*strongly

higher* moderately

School ESCS* strongly

School ESCS* moderately

Parent ESCS* strongly

Parent ESCS*moderately

Parent ESCS*school ESCS

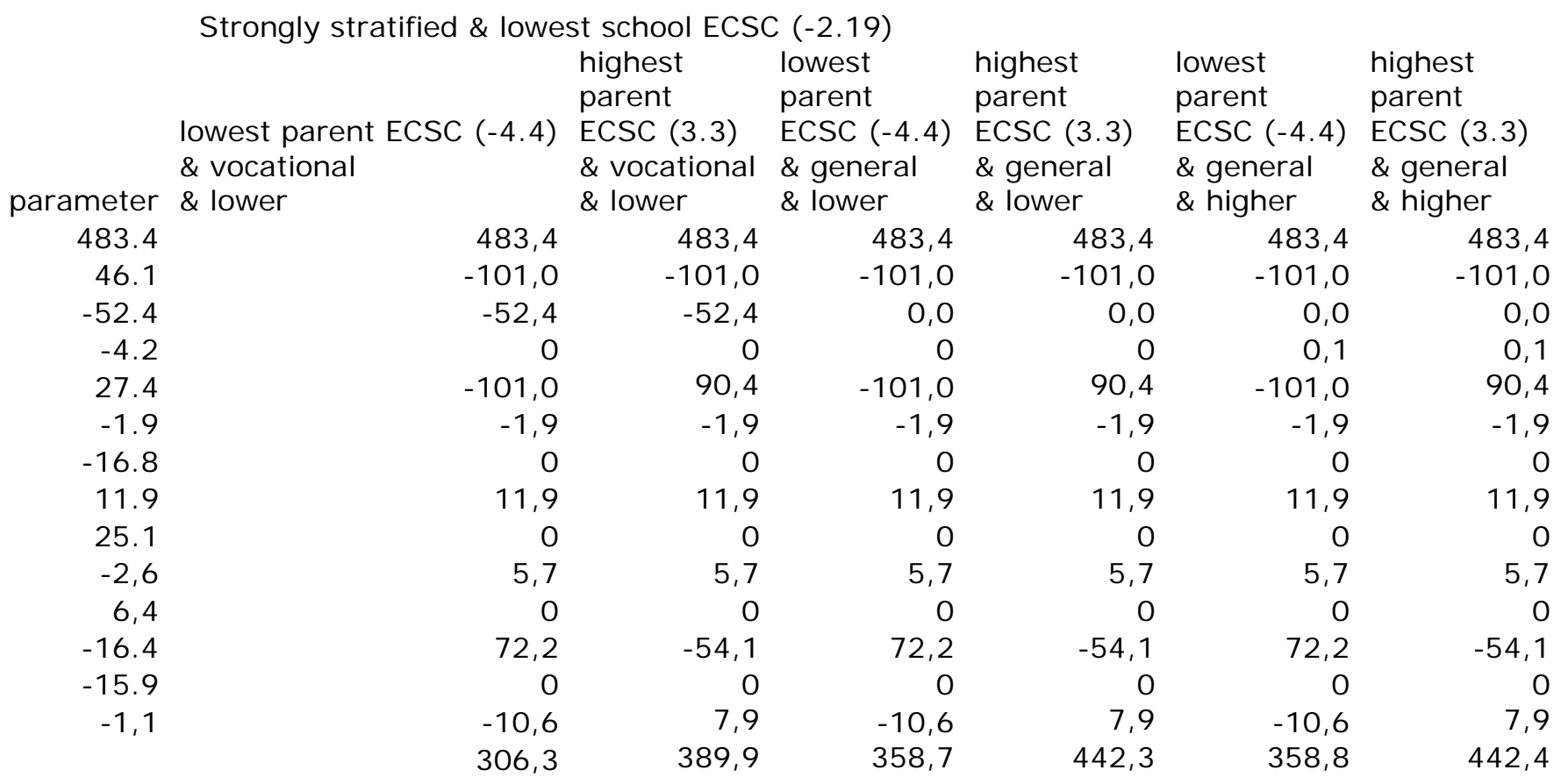


constant

School ESCS

vocational

higher secondary

Parent ESCS

strongly stratified

moderately stratified

higher*strongly

higher* moderately

School ESCS* strongly

School ESCS* moderately

Parent ESCS* strongly

Parent ESCS*moderately

Parent ESCS* school ESCS
Strongly stratified \& highest school ECSC (1.69)

highest lowest

parent parent

lowest parent ECSC (-4.4)

$\&$ vocational

parameter \& lower

483.4

46.1

$-52.4$

$-4.2$

27.4

$-1.9$

$-16.8$

11.9

25.1

$-2,6$

6,4

$-16.4$

$-15.9$

$-1,1$
$\&$ vocational \& general

$\&$ lower

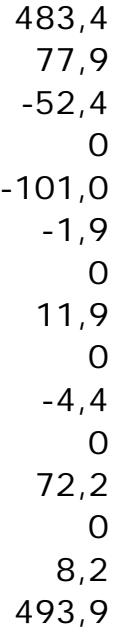

77,9

$-52,4$

01,0

$-1,9$

11,9

0
$-4,4$

0
72,2

8,2

493,9
483,

77,9

$-52,4$

0
90

90,4
$-1,9$

0

11,9

0
$-4,4$

0

$-54,1$

0
$-6,1$

544,7
$\&$ lower

483,4

77,9

0

$-101,0$

$-1,9$

11,9

0
$-4,4$
0

72,2

0

8,2

546,3 highest

parent

$\operatorname{ECSC}(3.3)$

$\&$ general

$\&$ lower

483,4

77,9

0

90

$-1,9$

11,9

0

$-4,4$

0
$-54,1$

0

$-6,1$

597,1 lowest highest

parent parent

$\operatorname{ECSC}(-4.4) \quad \operatorname{ECSC}(3.3)$

$\&$ general \& general

$\&$ higher \& higher

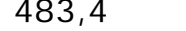

77,9

77,9

0,1

90,4

$-101,0$

$-1,9$

11,9

0
$-4,4$

$-54,1$

0

$-6,1$

597,2 